•研究报告・

\title{
自然保护区物种多样性保护价值评价方法
}

\author{
郭子良 ${ }^{1,2}$ 邢韶华 ${ }^{1}$ 崔国发 $^{1 *}$ \\ 1 (北京林业大学自然保护区学院, 北京 100083) \\ 2 (中国林业科学研究院湿地研究所, 北京 100091)
}

\begin{abstract}
摘要：如何客观地确定自然保护区的保护优先性, 为自然保护区的晋级和确定管理类型提供科学依据, 已成为当 前函待解决的问题。本研究通过对已有评价指标和方法的对比、专家咨询、评价指标量化处理, 提出了量化评价 自然保护区物种多样性保护价值的方法。此评价方法包括了自然保护区野生植物、野生动物、珍稀濒危野生植物 和珍稀濒危野生动物多样性保护价值指数等量化模型。同时我们应用此方法对华北暖温带区域的39个自然保护区 和东北温带区域的67个自然保护区的物种多样性保护价值进行了评价。结果表明, 位于华北暖温带区域的河北南 大港湿地和辽河源及北京雾灵山, 以及位于东北温带区域的黑龙江镜泊湖、大佳河和翠北湿地等省级自然保护区 的物种多样性保护价值较高, 可推荐优先晋级国家级自然保护区。该物种多样性保护价值评价方法能够较好地反 映自然保护区之间物种及各类群多样性保护价值的差异, 确定自然保护区保护优先序列。此外自然保护区物种多 样性保护价值在不同自然保护地理区和不同类型自然保护区之间存在显著差别。
\end{abstract}

关键词：自然保护区; 野生植物; 野生动物; 多样性; 保护价值

\section{A method for assessing species diversity conservation value of nature re- serves}

\author{
Ziliang Guo ${ }^{1,2}$, Shaohua Xing ${ }^{1}$, Guofa Cui ${ }^{1 *}$ \\ 1 College of Nature Conservation, Beijing Forestry University, Beijing 100083 \\ 2 Institute of Wetland Research, Chinese Academy of Forestry, Beijing 100091
}

\begin{abstract}
In order to provide a scientific basis for upgrading the level of a nature reserve (NR) and selecting the appropriate management type, the conservation priority of NRs should be identified. How to objectively identify conservation priorities has become a key problem. We propose a mathematical method to comprehensively assess species diversity conservation values by comparing existing evaluation indexes and methods, consulting experts and processing indexes quantitatively. This evaluation method includes the following indices: the wild plant diversity conservation value index; wild animal diversity conservation value index; rare and endangered wild plant diversity conservation value index; and the rare and endangered wild animal diversity conservation value index of a NR. Meanwhile, 39 NRs in North China Warm Temperate Region and 67 NRs in Northeast China Temperate Region were selected as case studies to verify methods, based on species diversity data of the NRs. The evaluation results revealed that some provincial NRs could be recommended for an upgrade to national NRs, due to high species diversity conservation values, including the Nandagang Wetland and Liaohe River Source NRs of Hebei, Wuling Mountain NR of Beijing in the North China Warm Temperate Region, the Jingpo Lake, Dajia River, and Cuibei Wetland NRs of Heilongjiang in the Northeast China Temperate Region. The computation method showed a great advantage in comparing species (various groups) diversity conservation values for different NRs and determining the conservation priority sequence. Moreover, there were significant differences in the species diversity conservation value of NR among different natural conservation geographical areas, and types of NRs.
\end{abstract}

Key words: nature reserve; wild plant; wild animal; diversity; conservation value

收稿日期: 2016-12-11; 接受日期: 2017-02-07

基金项目: 林业公益性行业科研专项(201104029)和北京林业大学青年教师科学研究中长期项目(2015ZCQ-BH-02)

*通讯作者 Author for correspondence. E-mail: fa6716@163.com 
生物多样性是自然生态系统健康和重要性的 主要表现形式(马克平，1993; Naeem et al，1994; Tilman et al, 1996)。近些年区域生物多样性丧失的 问题越来越严重, 其保护已成为人类共同面临的全 球性问题(Abell et al, 2008; Nelson et al, 2009; Rands et al, 2010)。保护生物多样性已成为自然保护区建 设的主要目标之一(Butchart et al, 2010; 马建章等, 2012)。截至目前, 全球已经建立了大量的自然保护 区，以期遏制区域野生动植物及其生境丧失的态势 (Jenkins \& Joppa, 2009)。如何评价这些自然保护区 的生物多样性保护价值和保护优先性受到了越来 越多的关注。研究人员提出了很多通过样方数据评 估物种多样性的指数方法, 一定程度上反映了其保 护价值, 包括 Simpson 指数、Shannon-Wiener 指数 等(McIntosh, 1967; Whittaker, 1972); 但是这些指数 在较大尺度的研究中却难以应用。而且多样性并不 能作为评价保护价值的唯一标准, 特有性、分类独 特性以及生境代表性等均应该成为评价内容 (Clarke \& Warwick, 1998; Veríssimo et al, 1998; Brooks et al, 2006; 王兵和宋庆丰, 2012)。“国际重要 湿地” (International Important Wetland)、“世界生物 圈保护区” (World Biosphere Reserve)等评估中均就 区域保护优先性和保护价值的评价指标和要求等 进行了描述。欧盟通过生境保护指令(European Commission Habitats Directive) 要求按照区域内物 种的稀有性、地理分布特征等确定其保护重要性, 作为保护区选址的参考(Gibbs et al, 2007; Mcgillivray, 2012)。

在我国, 李文华和赵献英(1984)首次提出从典 型性、稀有性、自然性、脆弱性等 9 个方面评价自 然保护区的保护价值, 并以此确定自然保护区的管 理等级。郑允文等(1994)参考其指标内容, 提出了自 然生态系统类和野生生物类自然保护区生态价值 的评价方法, 并对自然性、多样性和脆弱性等各项 指标进行了分析。而后研究人员基于此方法对我国 不同自然保护区的保护价值评价等开展了相关研 究(宋秀杰和赵制润, 1997; 张峥等, 2000; 奕晓峰等, 2002; 戚继忠和张吉春, 2004)。国家级自然保护区 的晋级评审中, 采用的《国家级自然保护区评审标 准》也应用了相似的评价指标, 并增加了相应的管 理指标。
科研人员对保护区保护价值的评价内容和等 级划分等进行了很多探讨和实践, 但多停留在定性 描述阶段(Humphries et al, 1995; Duelli \& Obrist, 2003; Timonen et al, 2011)。主要从生态系统和物种 的多样性、濒危性、特有性和独特性等方面评估自 然保护区的保护价值, 确定其保护优先性(Prendergast et al, 1993; Ceballos et al, 2008; 张恒庆和张文 辉, 2009; Primack 等, 2014)。近些年, 人们提出了多 种评价指标体系及其评分标准、数量化评估方法等, 并对其进行了应用验证(Freitag et al, 1997; 李霄宇, 2011; 孙锐等, 2013; 聂宇一, 2014 ${ }^{\circledR}$ )。但不同的评估 方法和模型对各个指标的量化赋值方式略有差异, 且多依赖于定性描述和专家打分等(Margules \& Pressey, 2000; Margules et al, 2002; 魏永久等, 2014)。 因此评价动机和专业背景等的差异可能影响生物 多样性评价指标的选择及其赋值(Duelli \& Obrist, 2003)。崔国发和孙锐(2014)以自然保护区水鸟的数 量, 以及不同水鸟的重要性等为基础, 对湿地自然 保护区的保护价值进行了测算和排序, 提出了新的 保护价值定量评价途径。本研究通过对已有评价指 标和方法的对比, 综合可靠性、可获得性等因素, 提出了一种定量化的自然保护区物种多样性保护 价值评价方法, 并进行了案例分析。

\section{1 评价方法}

\section{1 评价指标的选择}

物种多样性保护价值指生物多样性在物种层 次所表现的保护优先性。目前对自然保护区内物种 的保护价值评价指标很多, 但侧重点各有不同, 主 要集中在物种的珍稀濒危特征、地理分布特征和保 护等级等方面。在经过多次讨论和咨询 12 位野生 动植物和自然保护区管理方面专家的基础上, 本文 利用濒危性、特有性、保护等级和多样性(通过物种 种类变化反映)等来量化评价自然保护区物种多样 性的保护价值。

首先对野生动植物的濒危性、特有性和保护等 级 3 个指标进行量化, 得到其保护重要值(表 1, 表 2)。其中, 濒危性指物种濒临灭绝风险等级; 特有性 指物种在地理分布上的特有程度及特有等级; 保护 等级指物种在我国受法律保护等级。然后根据自然

(1) 聂宇一 (2014) 江西省森林生态类型自然保护区保护价值评价研究. 硕士学位论文, 江西师范大学, 南昌. 
表1 野生植物的保护重要性评价指标分级赋值标准

Table 1 Assignment for evaluation index of conservation importance of wild plants

\begin{tabular}{|c|c|c|c|c|}
\hline \multirow{2}{*}{$\begin{array}{c}\text { 评价指标 } \\
\text { Evaluation index }\end{array}$} & \multicolumn{4}{|c|}{ 分级赋值 Assignment } \\
\hline & 8 & 4 & 2 & 1 \\
\hline $\begin{array}{l}\text { 濒危性 } \\
\text { Endangerment }\end{array}$ & 极危 Critically Endangered & 濒危 Endangered & 易危 Vulnerable & $\begin{array}{l}\text { 近危和无危 Near } \\
\text { Threatened and Least } \\
\text { Concern }\end{array}$ \\
\hline 特有性 & 植物地区特有 & 植物亚区特有 & 中国特有 & 非中国特有 ～～ \\
\hline Endemism & Endemic to plant province & Endemic to plant subarea & Endemic to China & Not endemic to China \\
\hline 保护等级 & 国家一级保护或特殊保护 & 国家二级保护 & 地方重点保护 ～～～ & 其他 ～～～～ \\
\hline Conservation level & $\begin{array}{l}\text { First-category national protected or } \\
\text { special protected }\end{array}$ & $\begin{array}{l}\text { Second-category national } \\
\text { protected }\end{array}$ & Provincial key protected & Others \\
\hline
\end{tabular}

野生植物的濒危性根据国际和中国最新和最权威的物种红色名录中不同等级予以分级并赋值, 如《中国生物多样性红色名录一一高等植物 卷》等; 未评估和数据缺乏等按照无危赋分。植物地区和植被亚区的划分依据中国植物区系分区。特殊保护野生植物是指国家开展的特殊 保护工程中包括的野生植物，比如极小种群野生植物拯救保护工程。评价内容仅包括乡土物种。

Endangered wild plants can be graded and assigned according to the latest and most authoritative red list of species, such as "Red List of China's Biodiversity: Higher Plant Volume” etc. DD (Data Deficiency) and NE (Not Evaluated) are in accordance with LC (Least Concern). The division of plant province and subarea are according to Chinese Plant Flora. Special protected wild plants means plants in the special protection projects carried out by the state, such as the conservation project for extremely small population of wild plant. Evaluation objects only include native species.

\section{表 2 野生动物的保护重要性评价指标分级赋值标准}

Table 2 Assignment for evaluation index of conservation importance of wild animals

\begin{tabular}{|c|c|c|c|c|}
\hline \multirow{2}{*}{$\begin{array}{c}\text { 评价指标 } \\
\text { Evaluation index }\end{array}$} & \multicolumn{4}{|c|}{ 分级赋值 Assignment } \\
\hline & 8 & 4 & 2 & 1 \\
\hline $\begin{array}{l}\text { 濒危性 } \\
\text { Endangerment }\end{array}$ & 极危 Critically Endangered & 濒危 Endangered & 易危 Vulnerable & $\begin{array}{l}\text { 近危和无危 Near Threa- } \\
\text { tened and Least Concern }\end{array}$ \\
\hline 特有性 ${ }^{*}$ & 动物地理地区特有 & 中国特有 & 中国主要分布 & 中国次要或边缘分布 \\
\hline Endemism & Endemic to animal province & Endemic to China & $\begin{array}{l}\text { Distributed mainly } \\
\text { in China }\end{array}$ & $\begin{array}{l}\text { Distributed secondary or } \\
\text { marginal in China }\end{array}$ \\
\hline 保护等级 & 国家一级保护或特殊保护 & 国家二级保护 & 地方重点保护 & 其他 Others \\
\hline Conservation level & $\begin{array}{l}\text { First-category national protected } \\
\text { or special protected }\end{array}$ & $\begin{array}{l}\text { Second-category } \\
\text { national protected }\end{array}$ & $\begin{array}{l}\text { Provincial key } \\
\text { protected }\end{array}$ & \\
\hline
\end{tabular}

野生动物的濒危性根据国际和中国最新和最权威的物种红色名录中不同等级予以分级并赋值, 如《中国脊椎动物红色名录》等; 未评估和数 据缺乏等按照无危赋分。动物地理地区的划分依据中国动物地理区划。特殊保护野生动物是指国家开展的特殊保护工程中包括的野生动物。 “水鸟的特有性分级按照中国特有分布、中国主要分布、中国次要分布、中国边缘分布。

Endangered wild animals can be graded and assigned according to the latest and most authoritative red list of species, such as "Red list of China's vertebrates" etc. DD (Data Deficiency) and NE (Not Evaluated) are in accordance with LC (Least Concern). The division of zoogeographical regions is according to the Zoogeographical Regionalization of China. Special protected wild animals means animals included in the special protection projects carried out by the state. Evaluation objects only include native species.

"The endemism of waterfowl can be classified to Endemic to China, distributed mainly in China, distributed secondary in China, distributed marginal in China.

保护区内物种的种类和每个物种的保护重要值评 价该保护区的物种多样性保护价值。

\section{2 野生植物多样性保护价值评价}

(1)评价指标分级赋值

采用等比数列法进行赋值, 即后一项与前一项 的比数为常数, 设定最高赋值为 8 , 常数为 2 , 数列 为“8、4、2、1”; 具体分级赋值标准见表 1 。

(2)野生植物多样性保护价值指数计算

计算每种野生植物的保护重要值和自然保护 区野生植物多样性保护价值指数 $\left(V_{\mathrm{P}}\right)$, 公式如下:

$$
\begin{aligned}
& V_{\mathrm{Pi}}=T_{\mathrm{Pi}} \times E_{\mathrm{Pi}} \times P_{\mathrm{Pi}} \\
& V_{\mathrm{P}}=\sqrt{\sum_{\mathrm{i}=1}^{n} V_{\mathrm{Pi}}}
\end{aligned}
$$

式中, $V_{\mathrm{Pi}}$ 为野生植物 $\mathrm{i}$ 的保护重要值, 其取值数列 为 “ $1 、 2 、 4 、 8 、 16 、 32 、 64 、 128 、 256 、 512$ ”, 数 值越大表明物种的受威胁程度、地理分布特有程度 和重点保护级别越高, 其保护价值越高, 应予以优 先保护; $T_{\mathrm{Pi}}$ 为野生植物 $\mathrm{i}$ 的濒危性赋值; $E_{\mathrm{Pi}}$ 为野生 植物 $\mathrm{i}$ 的特有性赋值; $P_{\mathrm{Pi}}$ 为野生植物 $\mathrm{i}$ 的保护等级赋 值; $n$ 为自然保护区内野生植物种数。根据我国自然 保护区本底调查情况, 可选择维管束植物或高等植 物作为评价对象。

\section{3 野生动物多样性保护价值评价}

(1)评价指标分级赋值

同样采用等比数列法进行赋值, 即后一项与前 一项的比数为常数, 设定最高赋值为 8 , 常数为 2 , 
数列为“8、4、2、1”; 具体分级赋值标准见表 2 。

(2)野生动物多样性保护价值指数计算

计算每种野生动物的保护重要值和自然保护区 野生动物多样性保护价值指数 $\left(V_{\mathrm{A}}\right)$, 公式如下:

$$
\begin{aligned}
& V_{\mathrm{Ai}}=T_{\mathrm{Ai}} \times E_{\mathrm{Ai}} \times P_{\mathrm{Ai}} \\
& V_{\mathrm{A}}=\sqrt{\sum_{\mathrm{i}=1}^{m} V_{\mathrm{Ai}}}
\end{aligned}
$$

式中, $V_{\mathrm{Ai}}$ 为野生动物 $\mathrm{i}$ 的保护重要值, 其取值数列 为 “ $1 、 2 、 4 、 8 、 16 、 32 、 64 、 128 、 256 、 512$ ”, 数 值越大表明物种的受威胁程度、地理分布特有程度 和重点保护级别越高, 其保护价值越高, 应予以优 先保护; $T_{\mathrm{Ai}}$ 为野生动物 $\mathrm{i}$ 的濒危性赋值; $E_{\mathrm{Ai}}$ 为野生 动物 $\mathrm{i}$ 的特有性赋值; $P_{\mathrm{Ai}}$ 为野生动物 $\mathrm{i}$ 的保护等级 赋值; $m$ 为自然保护区内野生动物种数。根据我国 自然保护区本底调查情况, 选择陆生脊椎动物或脊 椎动物作为评价对象。

\section{4 珍稀濒危物种多样性保护价值评价}

珍稀濒危野生植物多样性保护价值指数 $\left(V_{\mathrm{PT}}\right)$ 计算公式如下:

$$
V_{\mathrm{PT}}=\sqrt{\sum_{\mathrm{i}=1}^{p} V_{\mathrm{Pi}}}
$$

式中, $V_{\mathrm{Pi}}$ 为珍稀濒危野生植物 $\mathrm{i}$ 的保护重要值; $p$ 为自 然保护区内珍稀濒危野生植物的种类数, 包括《中国 生物多样性红色名录一一高等植物卷》 (中华人民共 和国环境保护部和中国科学院, 2013)中极危和濒危 植物、国家重点保护野生植物以及极小种群植物。

珍稀濒危野生动物多样性保护价值指数 $\left(V_{\mathrm{AT}}\right)$ 计算公式如下:

$$
V_{\mathrm{AT}}=\sqrt{\sum_{\mathrm{i}=1}^{q} V_{\mathrm{Ai}}}
$$

式中, $V_{\mathrm{Ai}}$ 为珍稀濒危野生动物 $\mathrm{i}$ 的保护重要值; $q$ 为 自然保护区内珍稀濒危野生动物的种类数, 包括 《中国脊椎动物红色名录》(蒋志刚等, 2016)中极危 和濒危动物、国家重点保护野生动物。

\section{2 案例分析}

\section{1 数据来源及处理}

本研究选择了华北暖温带区域 39 个自然保护 区、东北温带区域 67 个自然保护区作为研究案例, 涉及黑龙江、吉林、辽宁、内蒙古、河北、北京、 天津和山西等 8 个省(市、自治区), 各自然保护区级
别为 2015 年数据。我们收集了这些自然保护区的 科学考察报告和总体规划中的野生动植物名录, 并 对其进行了数字化, 仅包括维管束植物和陆生脊椎 动物。按照每个自然保护区的主要自然地理景观, 可以将其划分为森林、湿地和草原草甸等类型。

参考《国家重点保护野生植物名录》(1998)、 《国家重点保护野生动物名录》(1989)、《中国生物 多样性红色名录一一高等植物卷》(中华人民共和国 环境保护部和中国科学院, 2013)、《中国脊椎动物红 色名录》(蒋志刚等, 2016)、各省区的省重点保护野 生动植物名录, 以及动植物志和野生动植物分类专 业网站信息, 对每个物种的不同属性进行分级赋值, 计算其保护重要值。

然后根据整理得到的每个自然保护区的野生 动植物名录和每个物种的保护重要值, 计算得到各 自然保护区野生植物多样性保护价值指数、野生动 物多样性保护价值指数等。各自然保护区所属自然 保护地理区参照中国自然保护综合地理区划方案 (郭子良和崔国发, 2014)。

\section{2 华北暖温带区域自然保护区物种多样性保护 价值}

华北暖温带区域各自然保护区物种多样性保 护价值指数如表 3 所示。以保护森林为主的自然保 护区野生植物多样性保护价值指数普遍较高, 其中 河北小五台山国家级自然保护区最高(46.70), 而且 其维管束植物多达 1,305 种。以保护湿地为主的自 然保护区野生植物多样性保护价值指数较低, 均低 于 20, 排在最后; 但是其野生动物多样性保护价值 指数均较高, 普遍高于 50 , 其中河北曹妃甸湿地和 鸟类省级自然保护区最高(52.89)。而以草原草甸为 主的自然保护区野生植物多样性和野生动物多样 性保护价值指数多处于中等水平。珍稀濒危野生植 物种类在各个自然保护区均很少, 特别是以湿地为 主的自然保护区, 均不超过 1 种。而珍稀濒危野生 动物种类在不同自然保护区均有一定数量, 但以保 护湿地为主的自然保护区普遍高于其他类型, 且其 珍稀濒危野生动物多样性保护价值指数也较高, 其 中河北南大港湿地自然保护区最高, $V_{\mathrm{AT}}$ 为 40.25 。

不同自然保护地理区的自然保护区物种多样 性保护价值存在巨大差异(表 3, 图 1, 图 2)。其中野 生植物多样性保护价值指数较高的自然保护区主 要集中在太行山东麓栽培植被与落叶阔叶林区 
表 3 华北暖温带区域部分自然保护区物种多样性保护价值指数(*截止到 2015 年确定的国家级自然保护区)

Table 3 The species diversity conservation value index of some nature reserves in North China Warm Temperate Region (* National nature reserve by 2015)

\begin{tabular}{|c|c|c|c|c|c|c|c|c|c|c|}
\hline $\begin{array}{l}\text { 自然保护地理区 } \\
\text { Natural conservation geograp- } \\
\text { hical area }\end{array}$ & $\begin{array}{l}\text { 自然保护区 } \\
\text { Nature reserve (NR) }\end{array}$ & $\begin{array}{l}\text { 省份 } \\
\text { Province }\end{array}$ & $N_{\mathrm{P}}$ & $V_{\mathrm{P}}$ & $N_{\mathrm{PT}}$ & $V_{\mathrm{PT}}$ & $N_{\mathrm{A}}$ & $V_{\mathrm{A}}$ & $N_{\text {AT }}$ & $V_{\mathrm{AT}}$ \\
\hline \multicolumn{11}{|l|}{ 森林 Forest } \\
\hline 辽西冀北山地落叶阔叶林区 & 努鲁儿虎山 Nuluerhu Mountain NR ${ }^{*}$ & 辽宁 Liaoning & 866 & 33.91 & 5 & 5.66 & 323 & 43.55 & 37 & 23.58 \\
\hline \multirow{4}{*}{$\begin{array}{l}\text { The North Hebei Province and } \\
\text { West Liaoning Province Moun- } \\
\text { tains Deciduous Broadleaf For- } \\
\text { est Area }\end{array}$} & 大黑山 Dahei Mountain NR* & 辽宁 Liaoning & 792 & 33.48 & 4 & 4.90 & 352 & 47.91 & 50 & 29.87 \\
\hline & 白狼山 Bailang Mountain NR ${ }^{*}$ & 辽宁 Liaoning & 799 & 33.02 & 5 & 5.66 & 198 & 31.76 & 19 & 13.71 \\
\hline & 虹螺山 Hongluo Mountain NR* & 辽宁 Liaoning & 783 & 32.83 & 8 & 7.21 & 197 & 31.89 & 18 & 14.00 \\
\hline & 海棠山 Haitang Mountain NR ${ }^{*}$ & 辽宁 Liaoning & 729 & 31.64 & 7 & 7.21 & 226 & 37.20 & 36 & 24.25 \\
\hline 七老图山落叶阔叶林与草原区 & 辽河源 Liaohe River Source NR & 河北 Hebei & 831 & 34.64 & 5 & 6.00 & 241 & 39.18 & 37 & 24.49 \\
\hline $\begin{array}{l}\text { Qilaotu Mountains Deciduous } \\
\text { Broadleaf Forest and Steppe } \\
\text { Area }\end{array}$ & 北大山 Beida Mountain NR & 河北 Hebei & 715 & 32.30 & 5 & 6.00 & 213 & 36.78 & 33 & 23.75 \\
\hline \multirow{9}{*}{$\begin{array}{l}\text { 燕山落叶阔叶林区 } \\
\text { Yanshan Mountains Deciduous } \\
\text { Broadleaf Forest Area }\end{array}$} & 松山 Songshan Mountain NR ${ }^{*}$ & 北京 Beijing & 740 & 34.07 & 7 & 10.39 & 167 & 29.10 & 19 & 15.10 \\
\hline & 雾灵山 Wuling Mountain NR & 北京 Beijing & 680 & 33.33 & 7 & 10.20 & 165 & 30.02 & 21 & 16.97 \\
\hline & $\begin{array}{l}\text { 青龙都山 } \\
\text { Dushan Mountain NR, Qinglong }\end{array}$ & 河北 Hebei & 691 & 32.3 & 6 & 6.63 & 203 & 33.27 & 28 & 20.49 \\
\hline & 青龙河 Qinglong River NR ${ }^{*}$ & 辽宁 Liaoning & 730 & 32.08 & 4 & 5.29 & 193 & 34.73 & 27 & 20.88 \\
\hline & 喇叭沟门 Labagoumen NR & 北京 Beijing & 622 & 29.97 & 4 & 5.29 & 152 & 30.35 & 24 & 19.08 \\
\hline & $\begin{array}{l}\text { 六里坪猕猴 } \\
\text { Liuliping Rhesus Monkeys NR }\end{array}$ & 河北 Hebei & 604 & 29.78 & 4 & 5.29 & 206 & 36.46 & 28 & 22.09 \\
\hline & $\begin{array}{l}\text { 宽城都山 Dushan Mountain NR, } \\
\text { Kuancheng }\end{array}$ & 河北 Hebei & 545 & 28.37 & 5 & 6.00 & 205 & 36.73 & 28 & 22.63 \\
\hline & $\begin{array}{l}\text { 宽城千鹤山 } \\
\text { Qianhe Mountain NR, Kuancheng }\end{array}$ & 河北 Hebei & 572 & 28.32 & 4 & 5.29 & 221 & 41.80 & 33 & 28.28 \\
\hline & 八仙山 Baxian Mountain NR* & 天津 Tianjin & 510 & 26.85 & 2 & 4.00 & 189 & 30.38 & 23 & 16.00 \\
\hline \multirow{5}{*}{$\begin{array}{l}\text { 晋北中山落叶阔叶林与草原区 } \\
\text { The North Shanxi Province } \\
\text { Mountains Deciduous Broad- } \\
\text { leaf Forest and Steppe Area }\end{array}$} & 驼梁 Tuoliang NR* & 河北 Hebei & 843 & 36.77 & 6 & 6.63 & 283 & 48.15 & 44 & 33.41 \\
\hline & 灵空山 Lingkong Mountain NR* & 山西 Shanxi & 811 & 34.60 & 6 & 7.75 & 215 & 39.01 & 33 & 25.61 \\
\hline & 芦芽山 Luya Mountain NR* & 山西 Shanxi & 651 & 30.97 & 3 & 4.90 & 299 & 44.38 & 40 & 28.21 \\
\hline & 银河山 Yinhe Mountain NR & 河北 Hebei & 613 & 30.40 & 2 & 4.00 & 175 & 32.37 & 23 & 19.18 \\
\hline & 漫山 Manshan Mountain NR & 河北 Hebei & 480 & 27.18 & 5 & 8.00 & 168 & 31.72 & 22 & 19.18 \\
\hline \multirow{8}{*}{$\begin{array}{l}\text { 太行山东麓栽培植被与落叶 } \\
\text { 阔叶林区 } \\
\text { The East Taihang Mountains } \\
\text { Cultivate Vegetation and De- } \\
\text { ciduous Broadleaf Forest Area }\end{array}$} & 小五台山 Xiaowutai Mountain NR* & 河北 Hebei & 1,305 & 46.70 & 9 & 14.56 & 150 & 33.78 & 23 & 25.30 \\
\hline & 青崖寨 Qingyazhai NR* & 河北 Hebei & 847 & 42.68 & 5 & 23.24 & 187 & 32.45 & 27 & 19.70 \\
\hline & 百花山 Baihua Mountain NR* & 北京 Beijing & 821 & 37.84 & 11 & 14.97 & 172 & 31.80 & 14 & 19.80 \\
\hline & 摩天岭 Motianling NR & 河北 Hebei & 775 & 34.31 & 6 & 6.63 & 177 & 33.78 & 23 & 22.09 \\
\hline & $\begin{array}{l}\text { 金华山-横岭子褐马鸡 } \\
\text { Jinhua Mountain-Henglingzi Brown } \\
\text { Eared-Pheasant NR }\end{array}$ & 河北 Hebei & 672 & 31.95 & 6 & 6.63 & 150 & 32.95 & 22 & 24.00 \\
\hline & 三峰山 Sanfeng Mountain NR & 河北 Hebei & 676 & 31.84 & 4 & 5.29 & 161 & 29.36 & 19 & 16.73 \\
\hline & 云蒙山 Yunmeng Mountain NR & 北京 Beijing & 514 & 27.29 & 2 & 4.00 & 123 & 26.80 & 13 & 16.49 \\
\hline & 大茂山 Damao Mountain NR & 河北 Hebei & 413 & 24.49 & 2 & 3.46 & 118 & 23.09 & 14 & 11.31 \\
\hline $\begin{array}{l}\text { 太行山南段山地落叶阔叶林 } \\
\text { 与湿地区 } \\
\text { The South Taihang Mountains } \\
\text { Deciduous Broadleaf Forest and } \\
\text { Wetland Area } \\
\text { 草原草甸 Steppe and Meadow }\end{array}$ & $\begin{array}{l}\text { 蟒河猕猴 } \\
\text { Manghe River Rhesus Monkeys NR* }\end{array}$ & 山西 Shanxi & 773 & 35.10 & 6 & 8.49 & 280 & 41.70 & 33 & 25.14 \\
\hline $\begin{array}{l}\text { 燕山落叶阔叶林区 } \\
\text { Yanshan Mountains Deciduous } \\
\text { Broadleaf Forest Area }\end{array}$ & 白草洼 Baicaowa NR & 河北 Hebei & 783 & 35.01 & 6 & 10.00 & 207 & 32.74 & 29 & 18.97 \\
\hline
\end{tabular}


表 3 (续) Table 3 (continued)

\begin{tabular}{|c|c|c|c|c|c|c|c|c|c|c|}
\hline $\begin{array}{l}\text { 自然保护地理区 } \\
\text { Natural conservation geograp- } \\
\text { hical area }\end{array}$ & $\begin{array}{l}\text { 自然保护区 } \\
\text { Nature reserve (NR) }\end{array}$ & $\begin{array}{l}\text { 省份 } \\
\text { Province }\end{array}$ & $N_{\mathrm{P}}$ & $V_{\mathrm{P}}$ & $N_{\mathrm{PT}}$ & $V_{\mathrm{PT}}$ & $N_{\mathrm{A}}$ & $V_{\mathrm{A}}$ & $N_{\text {AT }}$ & $V_{\mathrm{AT}}$ \\
\hline \multirow{9}{*}{$\begin{array}{l}\text { 湿地 Wetland } \\
\text { 海河平原栽培植被与湿地区 } \\
\text { Haihe Plain Cultivate Vegeta- } \\
\text { tion and Wetland Area }\end{array}$} & $\begin{array}{l}\text { 㴒河源草地 } \\
\text { Luanhe River Source Steppe NR }\end{array}$ & 河北 Hebei & 682 & 31.35 & 6 & 8.25 & 101 & 24.06 & 16 & 14.97 \\
\hline & 红松洼 Hongsongwa NR* & 河北 Hebei & 517 & 27.89 & 3 & 8.94 & 267 & 43.31 & 42 & 28.57 \\
\hline & 御道口 Yudaokou NR & 河北 Hebei & 495 & 27.33 & 3 & 6.93 & 196 & 39.32 & 36 & 28.35 \\
\hline & & & & & & & & & & \\
\hline & 曹妃甸湿地和鸟类 & 河北 Hebei & 217 & 16.09 & 0 & 0 & 297 & 52.89 & 55 & 39.24 \\
\hline & $\begin{array}{l}\text { Caofeidian Wetland and Bird NR } \\
\text { 衡水湖 Hengshui Lake NR }{ }^{*}\end{array}$ & 河北 Hebei & 285 & 18.63 & 1 & 2 & 339 & 52.86 & 58 & 36.93 \\
\hline & 南大港湿地 Nandagang Wetland NR & 河北 Hebei & 216 & 16.03 & 1 & 2 & 276 & 52.57 & 53 & 40.25 \\
\hline & $\begin{array}{l}\text { 古海岸与湿地 } \\
\text { Palecoast and Wetland NR* }\end{array}$ & 天津 Tianjin & 194 & 15.3 & 1 & 2 & 271 & 50.57 & 45 & 36.82 \\
\hline & 白洋淀 Baiyangdian NR & 河北 Hebei & 324 & 19.95 & 0 & 0 & 220 & 42.93 & 33 & 29.73 \\
\hline
\end{tabular}

$N_{\mathrm{P}}$ : 维管束植物种类; $V_{\mathrm{P}}$ : 野生植物多样性保护价值指数; $N_{\mathrm{PT}}$ : 珍稀濒危维管束植物种类; $V_{\mathrm{PT}}$ : 珍稀濒危野生植物多样性保护价值指数; $N_{\mathrm{A}}$ : 陆生脊椎动物种类; $V_{\mathrm{A}}$ : 野生动物多样性保护价值指数; $N_{\mathrm{AT}}$ : 珍稀濒危陆生脊椎动物种类; $V_{\mathrm{AT}}$ : 珍稀濒危野生动物多样性保护价值指数。

$N_{\mathrm{P}}$, Vascular plant species; $V_{\mathrm{P}}$, The wild plant diversity conservation value index; $N_{\mathrm{PT}}$, Rare and endangered vascular plant species; $V_{\mathrm{PT}}$, The rare and endangered wild plant diversity conservation value index; $N_{\mathrm{A}}$, Terrestrial vertebrate species; $V_{\mathrm{A}}$, The wild animal diversity conservation value index; $N_{\mathrm{AT}}$, Rare and endangered terrestrial vertebrate species; $V_{\mathrm{AT}}$, The rare and endangered wild animal diversity conservation value index.

及太行山南段山地落叶阔叶林与湿地区。但野生动 物多样性保护价值指数较高的自然保护区多分布 于海河平原栽培植被与湿地区, 该地理区的自然保 护区均以保护湿地为主。此外, 辽西冀北山地落叶 阔叶林区的辽宁大黑山和努鲁儿虎山、晋北中山落 叶阔叶林与草原区的河北驼梁和山西芦芽山国家 级自然保护区野生动物多样性保护价值指数也较 高, 均超过了 40 。

此外在不同自然保护地理区, 自然地理景观一 致的一些省级自然保护区野生植物或野生动物多 样性保护价值指数高于部分国家级自然保护区, 如 燕山落叶阔叶林区的北京雾灵山和河北宽城千鹤 山等省级自然保护区。评价结果表明, 河北辽河源、 北京雾灵山、河北摩天岭和河北白草洼等省级自然 保护区的野生植物多样性保护价值指数较高, 分别 为 34.64、33.33、34.31 和 35.01, 河北宽城千鹤山、 河北曹妃甸湿地和鸟类、河北南大港湿地和河北白 洋淀等省级自然保护区的野生动物多样性保护价值 指数较高, 分别为 $41.80 、 52.89 、 52.57$ 和 42.93 , 超 过了很多国家级自然保护区，应予以优先保护。

\section{3 东北温带区域自然保护区物种多样性保护价值}

东北温带区域的自然保护区物种多样性保护 价值指数评价结果见表 4。野生植物多样性保护价 值指数较高的自然保护区多以保护森林为主, 部分 以保护湿地为主。其中除吉林长白山和吉林松花江
三湖国家级自然保护区外, 其他自然保护区野生植 物多样性保护价值指数均低于 40 。以保护湿地和草 原草甸为主的大部分自然保护区野生植物多样性 保护价值指数相对较低, 但其野生动物多样性保护 价值指数较高。吉林松花江三湖国家级自然保护区 野生动物多样性保护价值指数最高(57.11); 其野生 动物种数(331)低于吉林莫莫格国家级自然保护区 (334)。此外, 东北温带区域不同自然保护区珍稀濒 危野生动植物多样性及其保护价值的差异也较明 显。其中吉林长白山和吉林松花江三湖国家级自然 保护区的珍稀濒危野生植物种类均超过 20 种, 其 保护价值较高; 但许多以保护湿地为主的自然保护 区珍稀濒危野生植物种类很少。该区域自然保护区 内珍稀濒危野生动物种类普遍超过 30 种, 不同类 型自然保护区之间差别不明显。野生动物多样性保 护价值指数较高的自然保护区, 其珍稀濒危野生动 物多样性保护价值指数同样较高。

东北温带区域不同自然保护地理区内自然保 护区的物种多样性保护价值也存在较大差异(表 4, 图 1, 图 2)。其中野生植物多样性保护价值指数较 高的自然保护区主要集中在纬度较低的龙岗山针 阔混交林区和辽东半岛落叶阔叶林与湿地区。但野 生动物多样性保护价值指数较高的自然保护区多 分布于张广才岭-完达山针阔混交林区、松嫩平原 栽培植被与草原草甸区和穆棱-三江平原湿地草甸 
区等地，其指数多高于 45。而长白山阔叶红松林区 内自然保护区野生植物和野生动物多样性保护价
值指数均很高, 其珍稀濒危物种多样性保护价值也 较高。

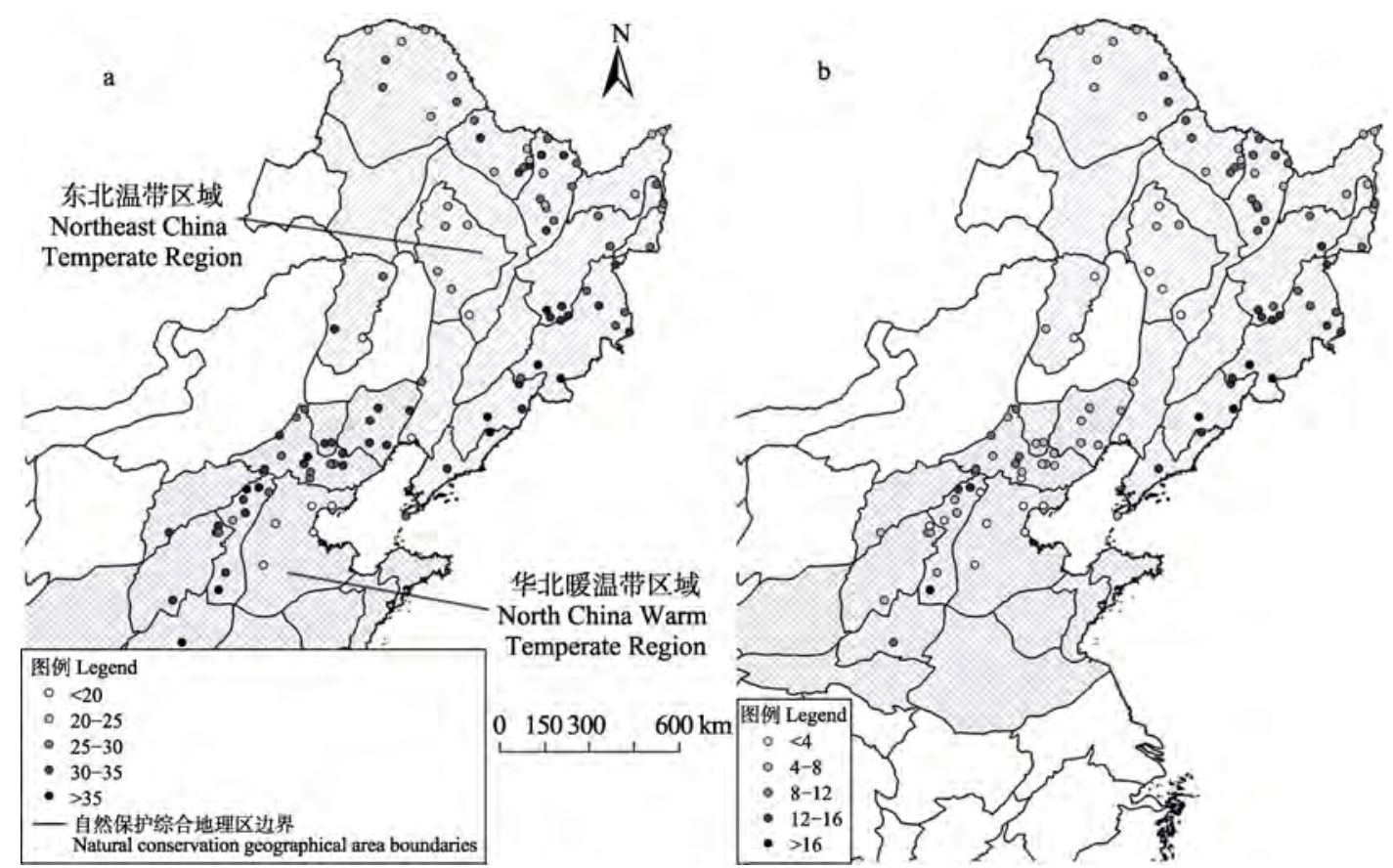

图 1 东北温带区域和华北暖温带区域部分自然保护区野生植物多样性保护价值指数(a)和珍稀濒危野生植物多样性保护价 值指数(b)分布图

Fig. 1 The pattern for the wild plant conservation value index (a) and rare and endangered wild plant conservation value index (b) of some nature reserves in Northeast China Temperate Region and North China Warm Temperate Region

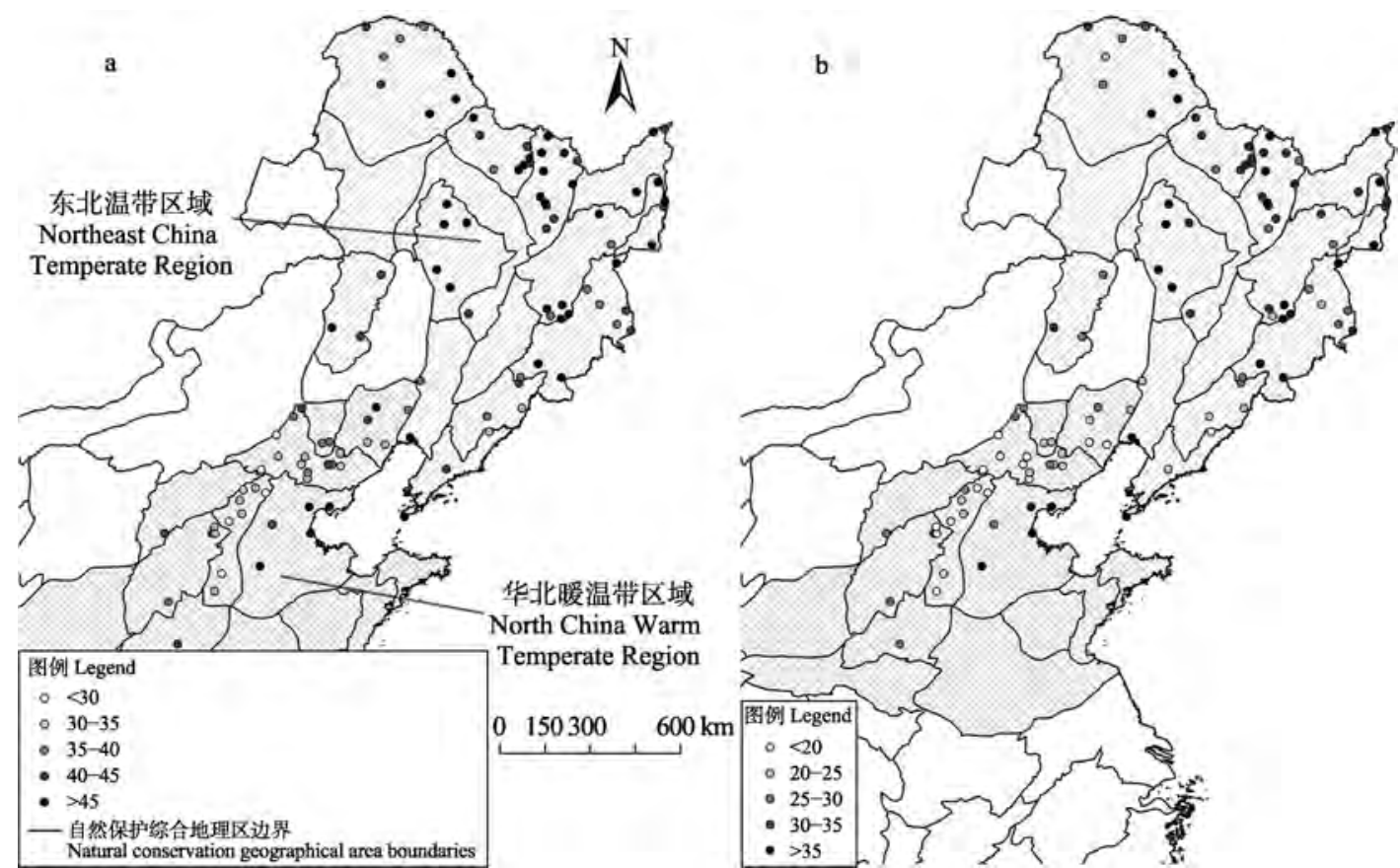

图 2 东北温带区域和华北暖温带区域部分自然保护区野生动物多样性保护价值指数(a)和珍稀濒危野生动物多样性保护价 值指数(b)分布图

Fig. 2 The pattern for the wild animal conservation value index (a) and rare and endangered wild animal conservation value index (b) of some nature reserves in Northeast China Temperate Region and North China Warm Temperate Region 
表 4 东北温带区域部分自然保护区物种多样性保护价值指数(* 截止到 2015 年确定的国家级自然保护区)

Table 4 The species diversity conservation value index of some nature reserves in Northeast China Temperate Region (* National nature reserve by 2015)

\begin{tabular}{|c|c|c|c|c|c|c|c|c|}
\hline $\begin{array}{l}\text { 自然保护地理区 } \\
\text { Natural conservation geogra- } \\
\text { phical area }\end{array}$ & $\begin{array}{l}\text { 自然保护区 } \\
\text { Nature reserve (NR) }\end{array}$ & $\begin{array}{l}\text { 省份 } \\
\text { Province }\end{array}$ & $N_{\mathrm{P}}$ & $V_{\mathrm{P}}$ & $N_{\mathrm{PT}} \quad V_{\mathrm{PT}}$ & $N_{\mathrm{A}}$ & $V_{\mathrm{A}}$ & $N_{\mathrm{AT}} \quad V_{\mathrm{AT}}$ \\
\hline
\end{tabular}

\section{森林 Forest}

大兴安岭北段落叶针叶林区 The North Daxing'an Mountains Deciduous Coniferous Forest Area

大兴安岭南段森林草原区

The South Daxing'an Mountains Forest and Steppe Area

小兴安岭北部针阔混交林区 The North Xiaoxing'an Mountains Coniferous and Broadleaf Mixed Forest Area

小兴安岭南部针阔混交林区 The South Xiaoxing'an Mountains Coniferous and Broadleaf Mixed Forest Area

辽河平原栽培植被与草原草 甸区 Liaohe Plain Cultivate Vegetation and Steppe Area 张广才岭-完达山针阔混交 林区 Zhangguangcai Mountains-Wanda Mountains Coniferous and Broadleaf Mixed Forest Area

长白山阔叶红松林区 Changbai Mountains Broadleaf Korean Pine Forest Area

\begin{tabular}{|c|c|c|c|c|c|c|c|c|c|c|}
\hline 岭峰 Lingfeng NR & 黑龙江 & Heilongjiang & 612 & 28.20 & 7 & 7.48 & 250 & 38.92 & 41 & 24.41 \\
\hline $\begin{array}{l}\text { 中央站黑嘴松鸡 Zhongyangzhan } \\
\text { Black-billed Capercaillie NR* }\end{array}$ & 黑龙江 & Heilongjiang & 588 & 27.69 & 11 & 8.72 & 324 & 49.26 & 61 & 35.33 \\
\hline 汗马 Khan Ma NR* & 内蒙古 & Inner Mongolia & 526 & 26.34 & 6 & 6.63 & 265 & 42.98 & 49 & 29.87 \\
\hline 盘中 Panzhong NR & 黑龙江 & Heilongjiang & 414 & 23.11 & 5 & 6.32 & 238 & 39.34 & 43 & 26.38 \\
\hline 北极村 Beijicun NR & 黑龙江 & Heilongjiang & 414 & 22.87 & 4 & 5.29 & 226 & 41.63 & 51 & 31.56 \\
\hline 乌兰坝 Wulanba NR* & 内蒙古 & Inner Mongolia & 824 & 32.57 & 5 & 6.32 & 296 & 47.30 & 50 & 32.80 \\
\hline 青山 Qingshan Mountain NR* & 内蒙古 & Inner Mongolia & 528 & 25.57 & 2 & 3.46 & 221 & 41.30 & 41 & 29.93 \\
\hline 胜山 Shengshan Mountain NR ${ }^{*}$ & 黑龙江 & Heilongjiang & 726 & 30.63 & 12 & 9.17 & 282 & 44.65 & 51 & 31.56 \\
\hline 友好 Youhao NR* & 黑龙江 & Heilongjiang & 634 & 28.91 & 11 & 8.94 & 285 & 46.68 & 45 & 33.47 \\
\hline Pingdin & 黑龙 & Heilongjiang & 724 & 31.26 & 12 & 9.17 & 253 & 40.36 & 39 & 27.13 \\
\hline
\end{tabular}

黑龙江 Heilongjiang

黑龙江 Heilongjiang

黑龙江 Heilongjiang

黑龙江 Heilongjiang

黑龙江 Heilongjiang

黑龙江 Heilongjiang

黑龙江 Heilongjiang

辽宁 Liaoning

黑龙江 Heilongjiang

大峡谷 Daxiagu NR*

黄泥河 Huangni River NR*

小北湖 Xiaobei Lake NR*

七星砬子东北虎

Qixinglazi Siberian Tiger NR

曙光 Shuguang NR

长白山 Changbai Mountain NR ${ }^{*}$

松花江三湖

Songhua River Three Lake NR*

穆棱东北红豆杉

Muling Japanese Yew NR*

珲春东北虎

Hunchun Siberian Tiger NR*

吉林 Jilin

黑龙江 Heilongjiang

黑龙江 Heilongjiang

黑龙江 Heilongjiang

吉林 Jilin

吉林 Jilin

吉林 Jilin

$\begin{array}{llllllll}654 & 29.17 & 10 & 8.72 & 249 & 41.22 & 43 & 28.07 \\ 626 & 28.69 & 11 & 8.94 & 268 & 47.02 & 48 & 35.94 \\ 502 & 25.87 & 10 & 8.72 & 261 & 44.33 & 44 & 32.06 \\ 482 & 25.50 & 10 & 8.49 & 281 & 45.65 & 51 & 32.68 \\ 501 & 25.00 & 6 & 6.32 & 283 & 46.94 & 48 & 35.04 \\ 447 & 24.56 & 9 & 8.49 & 306 & 50.16 & 58 & 37.31 \\ 439 & 24.31 & 9 & 8.49 & 266 & 44.63 & 40 & 31.69 \\ 492 & 25.57 & 5 & 6.00 & 237 & 37.78 & 30 & 20.59 \\ & & & & & & & \\ 861 & 35.26 & 15 & 14.00 & 284 & 45.71 & 43 & 32.43\end{array}$

$\begin{array}{llllllll}711 & 32.17 & 12 & 12.17 & 208 & 37.09 & 32 & 24.98\end{array}$

$\begin{array}{llllllll}592 & 30.92 & 7 & 10.77 & 327 & 51.43 & 57 & 37.68\end{array}$

$\begin{array}{llllllll}679 & 29.75 & 11 & 8.94 & 306 & 47.69 & 53 & 34.53\end{array}$

$\begin{array}{llllllll}543 & 29.09 & 13 & 13.42 & 237 & 38.73 & 34 & 25.14\end{array}$

$\begin{array}{llllllll}1,312 & 45.19 & 26 & 19.49 & 309 & 48.86 & 52 & 35.10\end{array}$

$\begin{array}{llllllll}1,236 & 42.81 & 20 & 18.55 & 331 & 57.11 & 62 & 44.54\end{array}$

黑龙江 Heilongjiang $\quad 805 \quad 33.12 \quad 13 \quad 10.95 \quad 203 \quad 36.19 \quad 33 \quad 24.17$

$\begin{array}{llllllll}663 & 32.28 & 12 & 15.10 & 279 & 44.81 & 44 & 31.11\end{array}$

黑龙江 Heilongjiang $\quad 607 \quad 30.46 \quad 13 \quad 13.27 \quad 310 \quad 50.18 \quad 53 \quad 36.99$ 
表 4 (续) Table 4 (continued)

\begin{tabular}{|c|c|c|c|c|c|c|c|c|c|c|}
\hline $\begin{array}{l}\text { 自然保护地理区 } \\
\text { Natural conservation geogra- } \\
\text { phical area }\end{array}$ & $\begin{array}{l}\text { 自然保护区 } \\
\text { Nature reserve (NR) }\end{array}$ & $\begin{array}{l}\text { 省份 } \\
\text { Province }\end{array}$ & $N_{\mathrm{P}}$ & $V_{\mathrm{P}}$ & $N_{\text {PT }}$ & $V_{\mathrm{PT}}$ & $N_{\mathrm{A}}$ & $V_{\mathrm{A}}$ & $N_{\mathrm{AT}}$ & $V_{\mathrm{AT}}$ \\
\hline & 汪清 Wangqing NR* & 吉林 Jilin & 538 & 29.98 & 14 & 14.56 & 233 & 39.55 & 35 & 25.85 \\
\hline & 牡丹峰 Mudanfeng NR* & 黑龙江 Heilongjiang & 627 & 29.85 & 10 & 11.31 & 241 & 39.89 & 38 & 28.00 \\
\hline & $\begin{array}{l}\text { 老爷岭东北虎 } \\
\text { Laoyeling Siberian Tiger NR* }\end{array}$ & 黑龙江 Heilongjiang & 550 & 27.75 & 12 & 10.77 & 238 & 40.34 & 38 & 28.07 \\
\hline \multirow{3}{*}{$\begin{array}{l}\text { 龙岗山针阔混交林区 } \\
\text { Longgang Mountains Conif- } \\
\text { erous and Broadleaf Mixed } \\
\text { Forest Area }\end{array}$} & 老秃顶子 Laotudingzi NR ${ }^{*}$ & 辽宁 Liaoning & 972 & 38.65 & 17 & 16.37 & 221 & 37.12 & 33 & 24.49 \\
\hline & 哈泥 Hani NR* & 吉林 Jilin & 689 & 32.11 & 13 & 13.42 & 257 & 40.72 & 38 & 26.23 \\
\hline & 通化石湖 Tonghua Shihu NR & 吉林 Jilin & 593 & 31.80 & 15 & 17.55 & 219 & 34.99 & 35 & 20.98 \\
\hline \multirow{2}{*}{$\begin{array}{l}\text { 辽东半岛落叶阔叶林与湿地 } \\
\text { 区 Liaodong Peninsula De- }\end{array}$} & 白石砬子 Baishilazi NR ${ }^{*}$ & 辽宁 Liaoning & 971 & 37.54 & 14 & 13.42 & 171 & 30.59 & 23 & 17.66 \\
\hline & 仙人洞 Xianrendong NR* & 辽宁 Liaoning & 729 & 33.05 & 9 & 12.49 & 331 & 42.63 & 41 & 22.00 \\
\hline
\end{tabular}
Wetland Area

\section{草原草甸}

\section{Steppe and Meadow}

大兴安岭南段森林草原区 The South Daxing'an Mountains Forest and Steppe Area

\section{湿地 Wetland}

大兴安岭北段落叶针叶林区

The North Daxing'an Mountains Deciduous Coniferous Forest Area

小兴安岭北部针阔混交林区 The North Xiaoxing'an Mountains Coniferous and Broadleaf Mixed Forest Area

小兴安岭南部针阔混交林区

The South Xiaoxing'an Mountains Coniferous and Broadleaf Mixed Area

松嫩平原外围蒙古栎、草原 草甸区 The Periphery of Songnen Plain Quercus mongolica and Steppe Area

松嫩平原栽培植被与草原草 甸区

Songnen Plain Cultivate Vegetation and Steppe Area

辽河平原栽培植被与草原草 甸区

Liaohe Plain Cultivate Vegetation and Steppe Area
阿鲁科尔沁 Ar Horqin NR*

内蒙古 Inner Mongolia $261 \quad 17.66 \quad 1 \quad r 2.00 \quad 184 \quad 40.55 \quad 37 \quad 29.73$

绰纳河 Chuona River NR*

多布库尔 Duobukuer NR*

双河 Shuanghe NR*

库尔滨河 Kuerbin River NR

大沾河湿地

Dazhan River Wetland NR

公别拉河 Gongbiela River NR

红星湿地 Hongxing Wetland NR*

翠北湿地 Cuibei Wetland NR

山口 Shankou NR

乌伊岭 Wuyiling NR*

细鳞河 Xilin River NR

新青白头鹤

Xinqing Hooded Crane NR ${ }^{*}$

波罗湖 Boluo Lake NR*

莫莫格 Momoge NR*

扎龙 Zhalong NR*

乌裕尔河 Wuyuer River NR*

查干湖 Chagan Lake NR*

明水 Mingshui NR*

辽河口 Liaohe River Estuary NR*
黑龙江 Heilongjiang

黑龙江 Heilongjiang

黑龙江 Heilongjiang

黑龙江 Heilongjiang

黑龙江 Heilongjiang

黑龙江 Heilongjiang

黑龙江 Heilongjiang

黑龙江 Heilongjiang

黑龙江 Heilongjiang

黑龙江 Heilongjiang

黑龙江 Heilongjiang

黑龙江 Heilongjiang

吉林 Jilin

吉林 Jilin

黑龙江 Heilongjiang

黑龙江 Heilongjiang

吉林 Jilin

黑龙江 Heilongjiang

$\begin{array}{llllllll}443 & 24.74 & 10 & 8.49 & 301 & 49.98 & 57 & 38.37 \\ 406 & 22.69 & 6 & 6.93 & 297 & 49.40 & 54 & 37.63 \\ 394 & 22.38 & 5 & 6.00 & 221 & 39.24 & 45 & 27.78 \\ 424 & 23.92 & 7 & 7.48 & 271 & 46.90 & 50 & 34.64 \\ 713 & 30.35 & 11 & 8.94 & 265 & 46.50 & 51 & 34.87 \\ 631 & 28.64 & 9 & 8.25 & 253 & 46.11 & 46 & 34.53 \\ 342 & 21.35 & 5 & 6.32 & 259 & 44.87 & 45 & 33.17 \\ 850 & 32.95 & 13 & 9.59 & 217 & 41.95 & 41 & 31.05 \\ 421 & 22.96 & 5 & 6.00 & 207 & 39.27 & 37 & 28.07 \\ 707 & 30.32 & 12 & 8.94 & 311 & 48.11 & 54 & 34.93 \\ 511 & 26.12 & 7 & 7.48 & 285 & 46.31 & 51 & 33.41 \\ 730 & 30.40 & 10 & 8.49 & 291 & 46.18 & 51 & 32.86 \\ 187 & 14.73 & 1 & 2.00 & 169 & 40.51 & 29 & 30.46\end{array}$

$\begin{array}{llllllll}332 & 20.07 & 2 & 3.46 & 334 & 52.88 & 53 & 38.11\end{array}$

$\begin{array}{llllllll}436 & 23.07 & 4 & 4.90 & 314 & 52.32 & 50 & 38.83\end{array}$

$\begin{array}{llllllll}431 & 22.56 & 1 & 2.00 & 314 & 52.28 & 50 & 38.83\end{array}$

$\begin{array}{llllllll}402 & 22.20 & 2 & 3.46 & 273 & 51.32 & 46 & 39.09\end{array}$

$\begin{array}{llllllll}452 & 23.19 & 3 & 4.47 & 271 & 45.61 & 37 & 31.43\end{array}$

$\begin{array}{llllllll}124 & 12.45 & 1 & 2.00 & 302 & 52.37 & 47 & 38.26\end{array}$ 
表 4 (续) Table 4 (continued)

\begin{tabular}{|c|c|c|c|c|c|c|c|c|c|c|}
\hline $\begin{array}{l}\text { 自然保护地理区 } \\
\text { Natural conservation geogra- } \\
\text { phical area }\end{array}$ & $\begin{array}{l}\text { 自然保护区 } \\
\text { Nature reserve (NR) }\end{array}$ & $\begin{array}{l}\text { 省份 } \\
\text { Province }\end{array}$ & $N_{\mathrm{p}}$ & $V_{\mathrm{P}}$ & $N_{\mathrm{PT}}$ & $V_{\mathrm{PT}}$ & $N_{\mathrm{A}}$ & $V_{\mathrm{A}}$ & $N_{\text {AT }}$ & $V_{\mathrm{AT}}$ \\
\hline \multirow{6}{*}{$\begin{array}{l}\text { 穆棱-三江平原湿地、草甸区 } \\
\text { Muling-Sanjiang Plain Wet- } \\
\text { land and Meadow Area }\end{array}$} & 兴凯湖 Xingkai Lake NR* & 黑龙江 Heilongjiang & 670 & 29.50 & 10 & 8.25 & 283 & 50.05 & 57 & 38.11 \\
\hline & $\begin{array}{l}\text { 黑瞎子岛 } \\
\text { Bolshoy Ussuriysky Island NR }\end{array}$ & 黑龙江 Heilongjiang & 453 & 24.06 & 8 & 7.21 & 274 & 48.15 & 48 & 35.38 \\
\hline & $\begin{array}{l}\text { 东方红湿地 } \\
\text { Dongfanghong Wetland NR* }\end{array}$ & 黑龙江 Heilongjiang & 683 & 30.00 & 11 & 8.72 & 274 & 46.11 & 47 & 33.29 \\
\hline & 三环泡 Sanhuanpao NR* & 黑龙江 Heilongjiang & 402 & 22.34 & 5 & 5.29 & 258 & 45.78 & 36 & 31.75 \\
\hline & 三江 Sanjiang NR ${ }^{*}$ & 黑龙江 Heilongjiang & 470 & 24.52 & 6 & 6.32 & 215 & 44.34 & 44 & 34.70 \\
\hline & 珍宝岛 Zhenbao Island NR* & 黑龙江 Heilongjiang & 385 & 22.65 & 7 & 7.21 & 228 & 42.10 & 37 & 30.79 \\
\hline \multirow{3}{*}{$\begin{array}{l}\text { 张广才岭-完达山针阔混交 } \\
\text { 林区 Zhangguangcai Moun- } \\
\text { tain-Wanda Mountains Con- } \\
\text { iferous and Broadleaf Mixed } \\
\text { Forest Area }\end{array}$} & 大佳河 Dajia River NR & 黑龙江 Heilongjiang & 486 & 25.08 & 6 & 6.63 & 322 & 55.49 & 63 & 43.77 \\
\hline & 雁鸣湖 Yanming Lake NR* & 吉林 Jilin & 819 & 34.83 & 14 & 14.70 & 324 & 50.40 & 53 & 35.72 \\
\hline & 镜泊湖 Jingpo Lake NR & 黑龙江 Heilongjiang & 754 & 32.77 & 14 & 13.56 & 289 & 49.96 & 52 & 38.47 \\
\hline $\begin{array}{l}\text { 长白山阔叶红松林区 } \\
\text { Changbai Mountains Broad- } \\
\text { leaf Korean Pine Forest Area }\end{array}$ & 龙湾 Longwan NR ${ }^{*}$ & 吉林 Jilin & 412 & 25.55 & 9 & 12.17 & 235 & 39.65 & 36 & 26.31 \\
\hline $\begin{array}{l}\text { 辽东半岛落叶阔叶林与湿地 } \\
\text { 区 Liaodong Peninsula Dec- } \\
\text { iduous Broadleaf Forest and } \\
\text { Wetland Area }\end{array}$ & $\begin{array}{l}\text { 蛇岛老铁山 } \\
\text { Snake Island-Laotie Mountain NR* }\end{array}$ & 辽宁 Liaoning & 560 & 28.34 & 4 & 7.75 & 331 & 51.27 & 59 & 36.33 \\
\hline
\end{tabular}

$N_{\mathrm{P}} 、 V_{\mathrm{P}} 、 N_{\mathrm{PT}} 、 V_{\mathrm{PT}} 、 N_{\mathrm{A}} 、 V_{\mathrm{A}} 、 N_{\mathrm{AT}} 、 V_{\mathrm{AT}}$ 同表 3。

$N_{\mathrm{P}}, V_{\mathrm{P}}, N_{\mathrm{PT}}, V_{\mathrm{PT}}, N_{\mathrm{A}}, V_{\mathrm{A}}, N_{\mathrm{AT}}, V_{\mathrm{AT}}$ were consistent with Table 3.

在很多自然保护地理区, 一些省级自然保护区 野生植物或野生动物多样性保护价值指数高于已 建国家级自然保护区。评价结果表明, 黑龙江镜泊 湖 $\left(V_{\mathrm{P}}\right.$ 为 32.77, $V_{\mathrm{A}}$ 为 49.96) 和黑龙江七星砬子东北 虎 $\left(V_{\mathrm{P}}\right.$ 为 29.75, $V_{\mathrm{A}}$ 为 47.69)省级自然保护区的野生 植物和野生动物多样性保护价值指数均较高; 黑龙 江岭峰、黑龙江平顶山和黑龙江翠北湿地等省级自 然保护区的野生植物多样性保护价值指数较高, 分 别为 28.20、31.26 和 32.95; 黑龙江库尔滨河、黑龙 江公别拉河、黑龙江黑瞎子岛、黑龙江大佳河和黑 龙江乌马河紫貂等省级自然保护区的野生动物多 样性保护价值指数较高, 分别为 46.90、46.11、 48.15、55.49 和 45.65, 超过了很多国家级自然保护 区，应予以优先保护。

\section{3 讨论}

生物多样性保护价值评估是确定自然保护区 重要性和保护优先性的重要手段和途径。目前很多 保护区体系均倾向于通过评估保护区(一定范围内) 的生物多样性所具有的保护价值, 来确定是否将其 纳入保护名单或网络中(李霄宇, 2011; 魏永久等, 2014)。目前对物种多样性的评估主要围绕濒危性、
稀有性、特有性, 以及保护等级等方面开展, 本研 究围绕以上评价内容, 构建了一种定量评价自然保 护区物种多样性保护价值的方法。但受数据来源限 制, 在珍稀濒危物种多样性保护价值指数的计算过 程中目前未包含珍稀濒危物种的个体数量, 而其个 体数量的差异将直接影响自然保护区保护价值的 高低, 在未来条件允许的情况下, 应考虑加入此指 标, 将“公式(5)”改进为 $V_{\mathrm{PT}}=\sqrt{\sum_{\mathrm{i}=1}^{p} V_{\mathrm{Pi}} \times Q_{\mathrm{Pi}}}, Q_{\mathrm{Pi}}$ 为 珍稀濒危野生植物 $\mathrm{i}$ 的个体数量。而在保护对象独 特的自然保护区，其生境的不可替代性较高, 这些 保护对象是该自然保护区内生境保护的旗舰种。可 以从其旗舰种的保护重要值、种群个体数量和生境 重要性等方面评价自然保护区旗舰种的保护价值, 计算公式如 $V_{\mathrm{F}}=V \times H_{\mathrm{R}} \times Q_{\mathrm{R}}, V_{\mathrm{F}}$ 为自然保护区内 旗舰种的保护价值指数, $V$ 为自然保护区内旗舰种 的保护重要值, $H_{\mathrm{R}}$ 为自然保护区内旗舰种的生境重 要性, $Q_{\mathrm{R}}$ 为自然保护区内旗舰种的相对数量; 将评 价结果与具有相同保护对象的自然保护区进行比 较, 确定其保护优先性。 
本研究中以自然保护区公开的野生动植物名 录为依据, 主要来自于自然保护区科学考察报告和 总体规划。在物种名录整理过程中, 未考虑各项资 料之间的出版年代差异, 也无法对其准确性进行验 证, 有些地区可能未包括进一步调查所发现的新分 布物种。但是这些数据误差对分析结果的影响可能 是有限的, 而且目前许多评估也仅以已知调查数据 或公开数据资料为依据。

对华北暖温带区域和东北温带区域的自然保 护区物种多样性保护价值进行评价时, 发现一些自 然保护区在野生植物和野生动物多样性保护价值 指数上的差异很大, 特别是内陆湿地与水域类型自 然保护区。因此在进行生物多样性保护价值评价和 排序时应考虑自然保护区主要保护自然地理景观 之间的差异。由于以保护湿地为主的自然保护区中 迁徙候鸟较多, 鸟类分布较集中, 其脊椎动物种数 普遍高于其他类型的自然保护区, 且珍稀濒危脊椎 动物种数也高于其他类型。东北温带区域的自然保 护区野生动物多样性保护价值指数普遍高于华北 暖温带区域, 这可能与我国东北温带区域仍保留有 大面积的天然森林和湿地生态系统, 以及人类干扰 程度较华北暖温带区域更弱等有关, 因此物种多样 性保护价值的比较应该在相同地理单元内进行。物 种种类数的多少对物种多样性保护价值有一定的 影响, 但并不能直接决定野生植物和野生动物多样 性保护价值。评价结果也与该自然保护区珍稀濒危 物种、特有物种和保护物种等的构成有关。如辽宁 仙人洞国家级自然保护区维管束植物总数低于黑 龙江镜泊湖和翠北湿地自然保护区, 但其珍稀濒危 和特有植物较多, 野生植物多样性保护价值指数高 于这两个自然保护区。

\section{4 结论}

(1)本研究提出了从野生植物、野生动物和珍稀 濒危物种等角度量化评价自然保护区物种多样性 保护价值的数学模型和方法。该方法主要选择濒危 性、特有性和保护等级三项指标来量化评价物种的 保护重要值, 再依据自然保护区内的物种种类来评 价自然保护区野生植物、野生动物和珍稀濒危物种 多样性保护价值等。

(2)通过案例分析, 进一步验证了本研究提出 的自然保护区物种多样性保护价值评价模型和方
法的科学性、实用性, 野生植物和野生动物多样性 保护价值指数均能够较好地反映自然保护区之间 物种及其各类群多样性保护价值的差异, 确定保护 优先序列, 能为自然保护区晋级和管理类型的确定 等提供依据, 并可以为保护成效评估提供参考。此 外, 其研究结果也可以反映不同自然保护地理区的 物种多样性保护价值和保护优先性。而且保护森 林、草原草甸和湿地等不同自然地理景观的自然保 护区, 其野生植物和野生动物多样性保护价值指数 存在显著差别。

(3)研究结果表明, 许多省级自然保护区的物 种多样性保护价值明显高于相同自然保护地理区 内已建国家级自然保护区。我国现有国家级自然保 护区体系应开展“自上而下”的优化布局, 提高其保 护有效性。华北暖温带区域河北曹妃甸湿地和鸟 类、河北南大港湿地、河北辽河源、河北宽城千鹤 山和北京雾灵山等省级自然保护区的物种多样性 保护价值较高, 可推荐优先晋级国家级。东北温带 区域黑龙江镜泊湖、黑龙江大佳河、黑龙江翠北湿 地、黑龙江黑瞎子岛、黑龙江平顶山和黑龙江岭峰 等省级自然保护区的物种多样性保护价值较高, 可 推荐优先晋级国家级。其中黑龙江翠北湿地自然保 护区已经在 2016 年 5 月国务院公布的国家级自然 保护区晋级名单中。

致谢: 审稿专家和责任编委对本文提出了宝贵的修 改建议, 特此感谢!

\section{参考文献}

Abell R, Thieme ML, Revenga C, Bryer M, Kottelat M, Bogutskaya N, Coad B, Mandrak N, Balderas SC, Bussing W, Stiassny MLJ, Skelton P, Allen GR, Unmack P, Naseka A, Ng R, Sindorf N, Robertson J, Armijo E, Higgins JV, Heibel TJ, Wikramanayake E, Olson D, López HL, Reis RE, Lundberg JG, Pérez MHS, Petry P (2008) Freshwater ecoregions of the world: a new map of biogeographic units for freshwater biodiversity conservation. BioScience, 58, 403-414.

Brooks TM, Mittermeier RA, da Fonseca GA, Gerlach J, Hoffmann M, Lamoreux JF, Mittermeier CG, Pilgrim JD, Rodrigues ASL (2006) Global biodiversity conservation priorities. Science, 313, 58-61.

Butchart SHM, Walpole M, Collen B, Strien AV, Scharlemann JPW, Almond REA, Baillie JEM, Bomhard B, Brown C, Bruno J, Carpenter KE, Carr GM, Chanson J, Chenery AM, 
Csirke J, Davidson NC, Dentener F, Foster M, Galli A, Galloway JN, Genovesi P, Gregory RD, Hockings M, Kapos V, Lamarque JF, Leverington F, Loh J, McGeoch MA, McRae L, Minasyan A, Morcillo MH, Oldfield TEE, Pauly D, Quader S, Revenga C, Sauer JR, Skolnik B, Spear D, Stanwell-Smith D, Stuart SN, Symes A, Tierney M, Tyrrell TD, Vié JC, Watson R (2010) Global biodiversity: indicators of recent declines. Science, 328, 1164-1168.

Ceballos G, Rodríguez P, Medellín RA (2008) Assessing conservation priorities in megadiverse Mexico: mammalian diversity, endemicity, and endangerment. Ecological Applications, 8, 8-17.

Clarke KR, Warwick RM (1998) A taxonomic distinctness index and its statistical properties. Journal of Applied Ecology, 35, 523-531.

Cui GF, Sun R (2014) Technique of Conservation Priority Assessment of Wetland Nature Reserves. China Forestry Publishing House, Beijing. (in Chinese) [崔国发, 孙锐 (2014) 湿地自然保护区保护优先性评价技术. 中国林业出版社, 北京.]

Duelli P, Obrist MK (2003) Biodiversity indicators: the choice of values and measures. Agriculture, Ecosystems and Environment, 98, 87-98.

Freitag S, Jaarsveld ASV, Biggs HC (1997) Ranking priority biodiversity areas: an iterative conservation value-based approach. Biological Conservation, 82, 263-272.

Gibbs D, While A, Jonas AEG (2007) Governing nature conservation: the European Union Habitats Directive and conflict around estuary management. Environment and Planning A, 39, 339-358.

Guo ZL, Cui GF (2014) The comprehensive geographical regionalization of China supporting natural conservation. Acta Ecologica Sinica, 34, 1284-1294. (in Chinese with English abstract) [郭子良, 崔国发 (2014) 中国自然保护综合地 理区划. 生态学报, 34, 1284-1294.]

Humphries CJ, And PHW, Wright RIV (1995) Measuring biodiversity value for conservation. Annual Review of Ecology and Systematics, 26, 93-111.

Jenkins CN, Joppa L (2009) Expansion of the global terrestrial protected area system. Biological Conservation, 142, 21662174.

Jiang ZG, Jiang JP, Wang YZ, Zhang E, Zhang YY, Li LL, Xie F, Cai B, Cao L, Zheng GM, Dong L, Zhang ZW, Ding P, Luo ZH, Ding CQ, Ma ZJ, Tang SH, Cao WX, Li CW, Hu HJ, Ma Y, Wu Y, Wang YX, Zhou KY, Liu SY, Chen YY, Li JT, Feng ZJ, Wang Y, Wang B, Li C, Song XL, Cai L, Zang CX, Zeng Y, Meng ZB, Fang HX, Ping XG (2016) Red list of China's vertebrates. Biodiversity Science, 24, 500-551. (in Chinese and in English) [蒋志刚, 江建平, 王 跃招, 张鹗, 张雁云, 李立立, 谢锋, 蔡波, 曹亮, 郑光 美, 董路, 张正旺, 丁平, 罗振华, 丁长青, 马志军, 汤宋 华, 曹文宣, 李春旺, 胡慧建, 马勇, 吴毅, 王应祥, 周开 亚, 刘少英, 陈跃英, 李家堂, 冯祚建, 王燕, 王斌, 李 成, 宋雪琳, 蔡蕾, 蔵春金金, 曾岩, 孟智斌, 方红霞, 平晓
鸽 (2016) 中国脊椎动物红色名录. 生物多样性, 24, 500-551.]

Li WH, Zhao XY (1984) Nature Reserves of China. The Commercial Press, Beijing. (in Chinese) [李文华, 赵献英 (1984) 中国的自然保护区. 商务印书馆, 北京.]

Li XY (2011) Conservation Value Evaluation and Reasonable Distribution of National Nature Reserve for Forest. PhD dissertation, Beijing Forestry University, Beijing. (in Chinese with English abstract) [李霄宇 (2011) 国家级森林类 型自然保护区保护价值评价及合理布局研究. 博士学位 论文, 北京林业大学, 北京.]

Luan XF, Xie YM, Du DC, Xu HF (2002) The ecological and management evaluation of Chongming Dongtan Birds Nature Reserve. Journal of Shanghai Normal University (Nature Sciences), 31(3), 73-79. (in Chinese with English abstract) [奕晓峰, 谢一民, 杜德昌, 徐宏发 (2002) 上海 崇明东滩鸟类自然保护区生态环境及有效管理评价. 上 海师范大学学报(自然科学版), 31(3), 73-79.]

Ma JZ, Rong K, Cheng K (2012) Research and practice on biodiversity in situ conservation in China: progress and prospect. Biodiversity Science, 20, 551-558. (in Chinese with English abstract) [马建章, 戎可, 程鲲 (2012) 中国 生物多样性就地保护的研究与实践. 生物多样性, 20, 551-558.]

Ma KP (1993) On the concept of biodiversity. Chinese Biodiversity, 1, 20-22. (in Chinese) [马克平 (1993) 试论 生物多样性的概念. 生物多样性, 1, 20-22.]

Margules CR, Pressey RL (2000) Systematic conservation planning. Nature, 405, 243-253.

Margules CR, Pressey RL, Williams PH (2002) Representing biodiversity: data and procedures for identifying priority areas for conservation. Journal of Biosciences, 27, 309-326.

Mcgillivray D (2012) Compensating biodiversity loss: The EU Commission's approach to compensation under article 6 of the habitats directive. Journal of Environmental Law, 24, 417-450.

McIntosh RP (1967) An index of diversity and the relation of certain concepts to diversity. Ecology, 48, 392-404.

Ministry of Environmental Protection of the People's Republic of China, Chinese Academy of Sciences (2013) Chinese Biodiversity Red List: Higher Plant Volume. (in Chinese) [中华人民共和国环境保护部和中国科学院 (2013) 中国 生物多样性红色名录—高等植物卷.] http://www.zhb.gov.cn/gkml/hbb/bgg/201309/t20130912_260 061.htm. (accessed on 2015-12-10)

Naeem S, Thompson LJ, Lawler SP, Lawton JH, Woodfin RM (1994) Declining biodiversity can alter the performance of ecosystem. Nature, 368, 734-737.

Nelson E, Mendoza G, Regetz J, Polasky S, Tallis H, Cameron DR, Chan KMA, Daily GC, Goldstein J, Kareiva PM, Lonsdorf E, Naidoo R, Ricketts TH, Shaw MR (2009) Modeling multiple ecosystem services, biodiversity conservation, commodity production, and tradeoffs at landscape scales. Frontiers in Ecology and the Environment, 7, 4-11. 
Prendergast JR, Quinn RM, Lawton JH, Eversham BC, Gibbons DW (1993) Rare species, the coincidence of diversity hotspots and conservation strategies. Nature, 365, 335-337.

Primack RB, Ma KP, Jiang ZG (2014) Conservation Biology. Science Press, Beijing. (in Chinese) [Primack RB, 马克平, 蒋志刚 (2014) 保护生物学. 科学出版社, 北京.]

Qi JZ, Zhang JC (2004) Ecological evaluation for Hunchun Nature Reserve. Journal of Beihua University (Natural Science), 5, 453-457. (in Chinese with English abstract) [戚 继忠, 张吉春 (2004) 珲春自然保护区生态评价. 北华大 学学报(自然科学版), 5, 453-457.]

Rands MR, Adams WM, Bennun L, Butchart SH, Clements A, Coomes D, Entwistle A, Hodge I, Kapos V, Scharlemann JP, Sutherland WJ, Vira B (2010) Biodiversity conservation: challenges beyond 2010. Science, 329, 1298-1303.

Song XJ, Zhao TR (1997) Study on ecological evaluation of Songshan Nature Reserve. Environmental Science, 18(4), 76-78. (in Chinese with English abstract) [宋秀杰, 赵彤润 (1997) 松山自然保护区的生态评价. 环境科学, 18(4), 76-78.]

Sun R, Cui GF, Lei T, Zheng YM (2013) An evaluation index system classifying the conservation value of wetland nature reserves based on AHP. Acta Ecologica Sinica, 33, 1952-1963. (in Chinese with English abstract) [孙锐, 崔国 发, 雷霆, 郑姚闽 (2013) 湿地自然保护区保护价值评价 方法. 生态学报, 33, 1952-1963.]

Tilman D, Wedin D, Knops J (1996) Productivity and sustainability influenced by biodiversity in grassland ecosystems. Nature, 379, 718-720.

Timonen J, Gustafsson L, Kotiaho JS, Mönkkönen M (2011) Hotspots in cold climate: conservation value of woodland key habitats in boreal forests. Biological Conservation, 144, 2061-2067.

Veríssimo A, Júnior CS, Stone S, Uhl C (1998) Zoning of tim- ber extraction in the Brazilian Amazon. Conservation Biology, 12, 128-136.

Wang B, Song QF (2012) Value assessing methods of species diversity conservation in forest ecosystem. Journal of Beijing Forestry University, 34, 155-160. (in Chinese with English abstract) [王兵, 宋庆丰 (2012) 森林生态系统物 种多样性保育价值评估方法. 北京林业大学学报, 34, 155-160.]

Wei YJ, Guo ZL, Cui GF (2014) Assessment methods on biodiversity conservation value in nature reserves: research progress. World Forestry Research, 27(5), 37-42. (in Chinese with English abstract) [魏永久, 郭子良, 崔国发 (2014) 国内外保护区生物多样性保护价值评价方法研究 进展. 世界林业研究, 27(5), 37-42.]

Whittaker RH (1972) Evolution and measurement of species diversity. Taxon, 21, 213-251.

Zhang HQ, Zhang WH (2009) Conservation Biology. Science Press, Beijing. (in Chinese) [张恒庆, 张文辉 (2009) 保护 生物学. 科学出版社, 北京.]

Zhang Z, Zhu L, Zhang JW, Wang X, Zhang T, Zhu T (2000) Study on ecological quality evaluation method for wetland in China. China Environmental Science, 20(Suppl.), 55-58. (in Chinese with English abstract) [张峥, 朱琳, 张建文, 王欣, 张涛, 朱䑣 (2000) 我国湿地生态质量评价方法的 研究. 中国环境科学, 20(增刊), 55-58.]

Zheng YW, Xue DY, Zhang GS (1994) Study on ecological evaluation criteria and standards for nature reserves in China. Rural Eco-Environment, 10(3), 22-25. (in Chinese with English abstract) [郑允文, 薛达元, 张更生 (1994) 我国自然保护区生态评价指标和评价标准. 农村生态环 境, 10(3), 22-25.]

(责任编委: 唐志尧 责任编辑: 间文杰)

\section{附录 Supplementary Material}

附录1 本研究选取的华北暖温带区域39个自然保护区基本信息(数据截至2015年)

Appendix 1 The basic information of 39 nature reserves selected from North China Warm Temperate Region in this paper (Data by 2015)

http://www.biodiversity-science.net/fileup/PDF/2016350-1.pdf

附录2 本研究选取的东北温带区域67个自然保护区基本信息(数据截至2015年)

Appendix 2 The basic information of 67 nature reserves selected from Northeast China Temperate Region in this paper (Data by 2015)

http://www.biodiversity-science.net/fileup/PDF/2016350-2.pdf 
郭子良, 邢韶华, 崔国发. 自然保护区物种多样性保护价值评价方法. 生物多样性, 2017, 25 (3): 312-324. http://www.biodiversity-science.net/CN/10.17520/biods.2016350

附录1 本研究选取的华北暖温带区域39个自然保护区基本信息(数据截至2015年)

Appendix 1 The basic information of 39 nature reserves selected from North China Warm Temperate Region in this paper (Data by 2015)

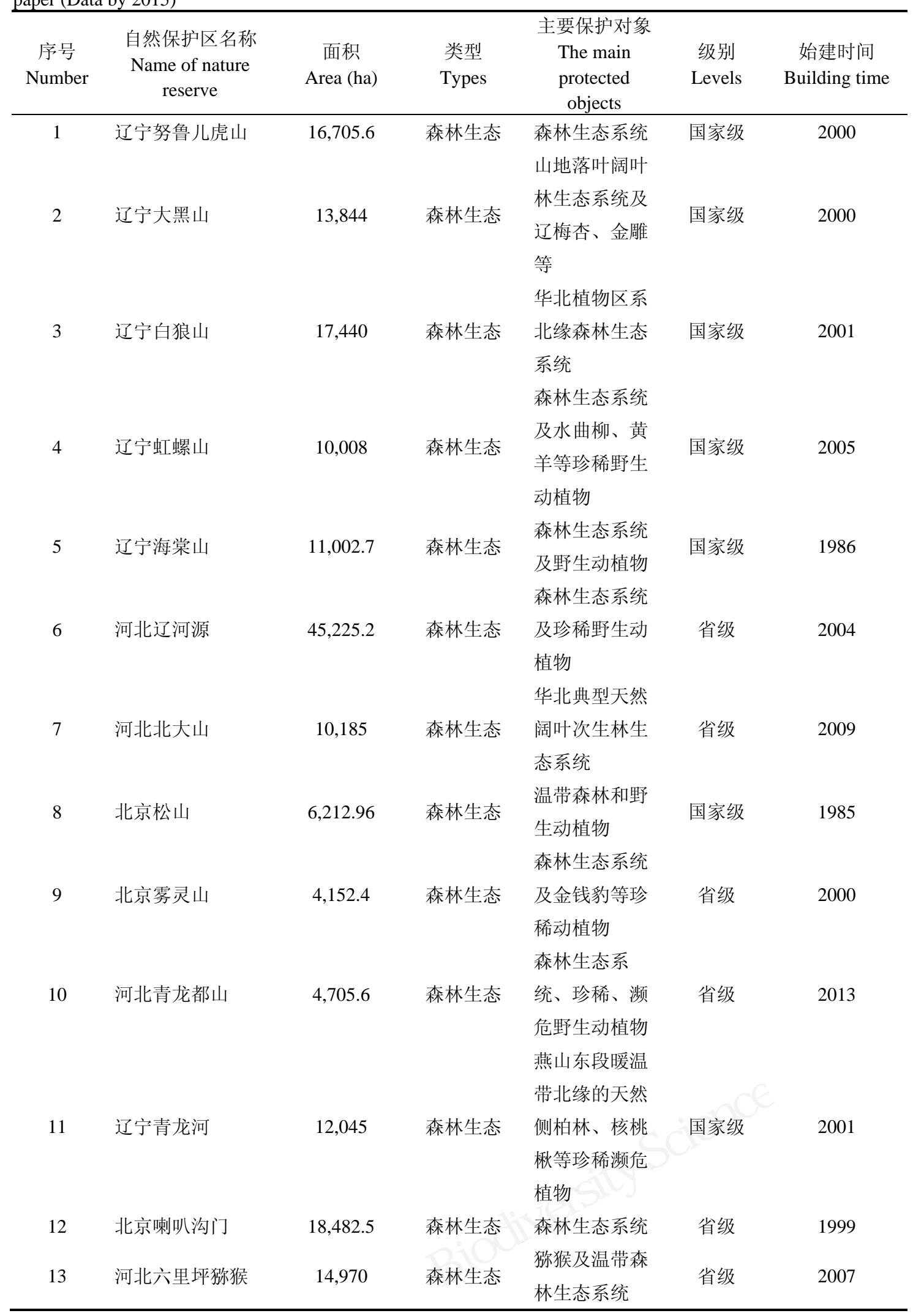




\begin{tabular}{|c|c|c|c|c|c|c|}
\hline $\begin{array}{c}\text { 序号 } \\
\text { Number }\end{array}$ & $\begin{array}{c}\text { 自然保护区名称 } \\
\text { Name of nature } \\
\text { reserve }\end{array}$ & $\begin{array}{c}\text { 面积 } \\
\text { Area (ha) }\end{array}$ & $\begin{array}{l}\text { 类型 } \\
\text { Types }\end{array}$ & $\begin{array}{c}\text { 主要保护对象 } \\
\text { The main } \\
\text { protected } \\
\text { objects } \\
\end{array}$ & $\begin{array}{c}\text { 级别 } \\
\text { Levels }\end{array}$ & $\begin{array}{c}\text { 始建时间 } \\
\text { Building time }\end{array}$ \\
\hline 14 & 河北宽城都山 & 19,648 & 森林生态 & $\begin{array}{l}\text { 森林生态系统 } \\
\text { 及珍稀野生动 } \\
\text { 植物 }\end{array}$ & 省级 & 2001 \\
\hline 15 & 河北宽城千鹤山 & $14,037.5$ & 野生动物 & 苍鹭及其生境 & 省级 & 2003 \\
\hline 16 & 天津八仙山 & 1,049 & 森林生态 & $\begin{array}{l}\text { 森林生态系统 } \\
\text { 褐马鸡及华北 }\end{array}$ & 国家级 & 1984 \\
\hline 17 & 山西芦芽山 & 21,453 & 野生动物 & $\begin{array}{l}\text { 落叶松、云杉 } \\
\text { 次生林 }\end{array}$ & 国家级 & 1980 \\
\hline 18 & 河北驼梁 & $21,311.9$ & 森林生态 & 森林生态系统 & 国家级 & 2001 \\
\hline 19 & 山西灵空山 & $10,116.8$ & 森林生态 & $\begin{array}{l}\text { 油松林和辽东 } \\
\text { 栋林等暖温带 } \\
\text { 落叶阔叶林生 } \\
\text { 态系统及褐马 } \\
\text { 鸡 }\end{array}$ & 国家级 & 1993 \\
\hline 20 & 河北银河山 & $36,210.9$ & 森林生态 & $\begin{array}{l}\text { 森林生态系 } \\
\text { 统、稀有地质 } \\
\text { 地貌资源 } \\
\text { 森林生态系统 }\end{array}$ & 省级 & 2012 \\
\hline 21 & 河北漫山 & 12,028 & 森林生态 & $\begin{array}{l}\text { 及珍稀野生动 } \\
\text { 植物 }\end{array}$ & 省级 & 2001 \\
\hline 22 & 河北小五台山 & 21,833 & 森林生态 & $\begin{array}{l}\text { 温带森林生态 } \\
\text { 系统及褐马鸡 }\end{array}$ & 国家级 & 1983 \\
\hline 23 & 河北青崖寨 & 15,164 & 森林生态 & $\begin{array}{l}\text { 森林及珍稀野 } \\
\text { 生动植物 }\end{array}$ & 国家级 & 2006 \\
\hline 24 & 北京百花山 & $21,743.1$ & 森林生态 & $\begin{array}{l}\text { 温带次生林 } \\
\text { 温带森林生态 }\end{array}$ & 国家级 & 1985 \\
\hline 25 & 河北摩天岭 & 35,100 & 森林生态 & $\begin{array}{l}\text { 系统及野生动 } \\
\text { 植物 }\end{array}$ & 省级 & 2012 \\
\hline 26 & $\begin{array}{l}\text { 河北金华山 -横岭 } \\
\text { 子褐马鸡 }\end{array}$ & 33,940 & 野生动物 & $\begin{array}{l}\text { 褐马鸡及其生 } \\
\text { 境 } \\
\text { 森林生态系统 }\end{array}$ & 省级 & 2003 \\
\hline 27 & 河北三峰山 & $5,464.7$ & 森林生态 & $\begin{array}{l}\text { 及珍稀野生动 } \\
\text { 植物 }\end{array}$ & 省级 & 2012 \\
\hline 28 & 北京云蒙山 & 3,900 & 森林生态 & $\begin{array}{l}\text { 森林生态系统 } \\
\text { 森林生态系统 }\end{array}$ & 省级 & 2000 \\
\hline 29 & 河北大茂山 & $1,353.33$ & 森林生态 & $\begin{array}{l}\text { 及珍稀野生动 } \\
\text { 植物、自然文 } \\
\text { 化遗产 }\end{array}$ & 省级 & 2012 \\
\hline
\end{tabular}


郭子良, 邢韶华, 崔国发. 自然保护区物种多样性保护价值评价方法. 生物多样性, 2017, 25 (3): 312-324. http://www.biodiversity-science.net/CN/10.17520/biods.2016350

\begin{tabular}{|c|c|c|c|c|c|c|}
\hline $\begin{array}{c}\text { 序号 } \\
\text { Number }\end{array}$ & $\begin{array}{c}\text { 自然保护区名称 } \\
\text { Name of nature } \\
\text { reserve }\end{array}$ & $\begin{array}{c}\text { 面积 } \\
\text { Area (ha) }\end{array}$ & $\begin{array}{l}\text { 类型 } \\
\text { Types }\end{array}$ & $\begin{array}{c}\text { 主要保护对象 } \\
\text { The main } \\
\text { protected } \\
\text { objects }\end{array}$ & $\begin{array}{c}\text { 级别 } \\
\text { Levels }\end{array}$ & $\begin{array}{c}\text { 始建时间 } \\
\text { Building time }\end{array}$ \\
\hline 30 & 山西蟒河猕猴 & 5,600 & 野生动物 & $\begin{array}{l}\text { 猕猴等珍稀野 } \\
\text { 生动植物 }\end{array}$ & 国家级 & 1983 \\
\hline 31 & 河北白草洼 & 17,680 & 草原草甸 & 森林草原 & 省级 & 2007 \\
\hline 32 & 河北㴒河源草地 & 21,500 & 草原草甸 & 草地生态系统 & 省级 & 1997 \\
\hline 33 & 河北红松洼 & 7,970 & 草原草甸 & 草原生态系统 & 国家级 & 1994 \\
\hline 34 & 河北御道口 & 32,620 & 草原草甸 & $\begin{array}{l}\text { 草原、湿地生 } \\
\text { 态系统 }\end{array}$ & 省级 & 2002 \\
\hline 35 & $\begin{array}{l}\text { 河北曹妃甸湿地 } \\
\text { 和鸟类 }\end{array}$ & $10,081.4$ & 内陆湿地 & $\begin{array}{l}\text { 湿地生态系统 } \\
\text { 及鸟类 }\end{array}$ & 省级 & 2004 \\
\hline 36 & 河北衡水湖 & 16,365 & 内陆湿地 & $\begin{array}{l}\text { 湿地生态系统 } \\
\text { 及鸟类 }\end{array}$ & 国家级 & 2000 \\
\hline 37 & 河北南大港湿地 & 7,500 & 内陆湿地 & $\begin{array}{l}\text { 湿地生态系统 } \\
\text { 及鸟类 }\end{array}$ & 省级 & 1995 \\
\hline 38 & $\begin{array}{l}\text { 天津古海岸与湿 } \\
\text { 地 }\end{array}$ & 35,913 & 海洋海岸 & $\begin{array}{l}\text { 贝壳堤、牡蚛 } \\
\text { 滩古海岸遗 } \\
\text { 迹、滨海湿地 }\end{array}$ & 国家级 & 1984 \\
\hline 39 & 河北白洋淀 & 29,696 & 内陆湿地 & $\begin{array}{l}\text { 湿地生态系统 } \\
\text { 及野生动植物 }\end{array}$ & 省级 & 2002 \\
\hline
\end{tabular}


郭子良, 邢韶华, 崔国发. 自然保护区物种多样性保护价值评价方法. 生物多样性, 2017, 25 (3): 312-324. http://www.biodiversity-science.net/CN/10.17520/biods.2016350

附录2 本研究选取的东北温带区域67个自然保护区基本信息(数据截至2015年)

Appendix 2 The basic information of 67 nature reserves selected from Northeast China Temperate Region in this paper (Data by 2015)

\begin{tabular}{|c|c|c|c|c|c|c|}
\hline $\begin{array}{c}\text { 序号 } \\
\text { Number }\end{array}$ & $\begin{array}{c}\text { 自然保护区名称 } \\
\text { Name of nature } \\
\text { reserve }\end{array}$ & $\begin{array}{c}\text { 面积 } \\
\text { Area (ha) }\end{array}$ & $\begin{array}{l}\text { 类型 } \\
\text { Types }\end{array}$ & $\begin{array}{c}\text { 主要保护对象 } \\
\text { The main protected } \\
\text { objects }\end{array}$ & $\begin{array}{c}\text { 级别 } \\
\text { Levels }\end{array}$ & $\begin{array}{c}\text { 始建时间 } \\
\text { Building } \\
\text { time }\end{array}$ \\
\hline 1 & 黑龙江岭峰 & 68,373 & 森林生态 & $\begin{array}{l}\text { 寒温带针叶林及 } \\
\text { 紫貂、原鹿、貂熊 } \\
\text { 等濒危野生动物 }\end{array}$ & 省级 & 2002 \\
\hline 2 & $\begin{array}{l}\text { 黑龙江中央站黑嘴 } \\
\text { 松鸡 }\end{array}$ & 46,743 & 野生动物 & $\begin{array}{l}\text { 黑嘴松鸡等珍稀 } \\
\text { 野生动植物以及 } \\
\text { 寒温带针叶林与 } \\
\text { 温带针阔叶混交 } \\
\text { 林过渡带的典型 } \\
\text { 森林生态系统 }\end{array}$ & 国家级 & 2006 \\
\hline 3 & 内蒙古汗马 & 107,348 & 森林生态 & $\begin{array}{l}\text { 寒温带苔原山地 } \\
\text { 明亮针叶林 }\end{array}$ & 国家级 & 1995 \\
\hline 4 & 黑龙江盘中 & 55,074 & 森林生态 & $\begin{array}{l}\text { 寒温带针叶林生 } \\
\text { 态系统及野生动 } \\
\text { 植物 }\end{array}$ & 省级 & 2006 \\
\hline 5 & 黑龙江北极村 & 137,553 & 森林生态 & $\begin{array}{l}\text { 寒温带森林生态 } \\
\text { 系统、森林湿地生 } \\
\text { 态系统 }\end{array}$ & 省级 & 2006 \\
\hline 6 & 内蒙古乌兰坝 & 78,672 & 森林生态 & $\begin{array}{l}\text { 西辽河源头区的 } \\
\text { 山地森林、湿地生 } \\
\text { 态系统, 斑羚、马 } \\
\text { 鹿和黑鹳等珍稀 } \\
\text { 动植物 }\end{array}$ & 国家级 & 1997 \\
\hline 7 & 内蒙古青山 & 26,989 & 森林生态 & $\begin{array}{l}\text { 蒙古栎林、黑桦 } \\
\text { 林、紫椴林等典型 } \\
\text { 温带天然林与草 } \\
\text { 原草甸生态系统 } \\
\text { 以及野大豆 }\end{array}$ & 国家级 & 1997 \\
\hline 8 & 黑龙江胜山 & 60,000 & 森林生态 & $\begin{array}{l}\text { 我国最北端的温 } \\
\text { 带森林生态系统 } \\
\text { 和红松、驼鹿等珍 } \\
\text { 稀濒危动植物 }\end{array}$ & 国家级 & 2003 \\
\hline 9 & 黑龙江友好 & 60,687 & 内陆湿地 & $\begin{array}{l}\text { 森林沼泽生态系 } \\
\text { 统及珍稀动植物 }\end{array}$ & 国家级 & 2001 \\
\hline 10 & 黑龙江平顶山 & 20,241 & 森林生态 & $\begin{array}{l}\text { 典型的小兴安岭 } \\
\text { 森林生态系统及 } \\
\text { 珍稀濒危野生动 } \\
\text { 植物 }\end{array}$ & 省级 & 2010 \\
\hline
\end{tabular}


郭子良, 邢韶华, 崔国发. 自然保护区物种多样性保护价值评价方法. 生物多样性, 2017, 25 (3): 312-324. http://www.biodiversity-science.net/CN/10.17520/biods.2016350

\begin{tabular}{|c|c|c|c|c|c|c|}
\hline $\begin{array}{c}\text { 序号 } \\
\text { Number }\end{array}$ & $\begin{array}{c}\text { 自然保护区名称 } \\
\begin{array}{c}\text { Name of nature } \\
\text { reserve }\end{array}\end{array}$ & $\begin{array}{c}\text { 面积 } \\
\text { Area (ha) }\end{array}$ & $\begin{array}{l}\text { 类型 } \\
\text { Types }\end{array}$ & $\begin{array}{c}\text { 主要保护对象 } \\
\text { The main protected } \\
\text { objects }\end{array}$ & $\begin{array}{c}\text { 级别 } \\
\text { Levels }\end{array}$ & $\begin{array}{c}\text { 始建时间 } \\
\text { Building } \\
\text { time }\end{array}$ \\
\hline 11 & 黑龙江太平沟 & 22,199 & 森林生态 & $\begin{array}{l}\text { 温带森林生态系 } \\
\text { 统及黑熊、棕熊等 } \\
\text { 珍稀野生动植物 }\end{array}$ & 国家级 & 2009 \\
\hline 12 & 黑龙江茅兰沟 & 35,868 & 森林生态 & $\begin{array}{l}\text { 温带森林生态系 } \\
\text { 统及原㭩、中华秋 } \\
\text { 沙鸭、红松等珍稀 } \\
\text { 野生动植物 }\end{array}$ & 国家级 & 1999 \\
\hline 13 & 黑龙江朗乡 & 31,355 & 森林生态 & $\begin{array}{l}\text { 原瘪等野生动物 } \\
\text { 及红松林生态系 } \\
\text { 统 }\end{array}$ & 国家级 & 2004 \\
\hline 14 & 黑龙江乌 & 20,949 & 野生动物 & $\begin{array}{l}\text { 紫貂小兴安岭亚 } \\
\text { 种及森林生态系 } \\
\text { 统 }\end{array}$ & 省级 & 2006 \\
\hline 15 & 黑龙江丰林 & 18,400 & 森林生态 & $\begin{array}{l}\text { 为以红松为主的 } \\
\text { 北温带针阔叶混 } \\
\text { 交林生态系统和 } \\
\text { 珍稀的野生动物 } \\
\text { 植物资源 }\end{array}$ & 国家级 & 1958 \\
\hline 16 & 黑龙江凉水 & 12,133 & 森林生态 & $\begin{array}{l}\text { 以红松为主的温 } \\
\text { 带针润叶混交林 } \\
\text { 及其生态系统 }\end{array}$ & 国家级 & 1980 \\
\hline 17 & $\begin{array}{l}\text { 黑龙江碧水中华秋 } \\
\text { 沙鸭 }\end{array}$ & 2,535 & 野生动物 & $\begin{array}{l}\text { 中华秋沙鸭及红 } \\
\text { 松林生态系统 }\end{array}$ & 省级 & 1997 \\
\hline 18 & 辽宁章古台 & 10,200 & 森林生态 & $\begin{array}{l}\text { 沙地森林生态系 } \\
\text { 统 }\end{array}$ & 国家级 & 1986 \\
\hline 19 & 黑龙江大峡谷 & 24,998 & 森林生态 & $\begin{array}{l}\text { 典型的东北山地 } \\
\text { 森林生态系统及 } \\
\text { 东北红豆杉 }\end{array}$ & 国家级 & 2010 \\
\hline 20 & 吉林黄泥河 & 41,583 & 森林生态 & $\begin{array}{l}\text { 北温带森林生态 } \\
\text { 系统及多种珍稀 } \\
\text { 濒危野生动植物 }\end{array}$ & 国家级 & 2000 \\
\hline 21 & 黑龙江小北湖 & 20,834 & 森林生态 & $\begin{array}{l}\text { 红松林生态系统 } \\
\text { 及原鹰、紫貂等珍 } \\
\text { 稀动植物 }\end{array}$ & 国家级 & 2006 \\
\hline 22 & $\begin{array}{l}\text { 黑龙江七星砬子东 } \\
\text { 北虎 }\end{array}$ & 55,740 & 野生动物 & $\begin{array}{l}\text { 东北虎、马鹿等野 } \\
\text { 生动物及其生境 }\end{array}$ & 省级 & 1980 \\
\hline 23 & 黑龙江曙光 & 9,766 & 野生动物 & $\begin{array}{l}\text { 天蚕及柞林生态 } \\
\text { 系统 }\end{array}$ & 省级 & 1992 \\
\hline 24 & 吉林长白山 & 196,465 & 森林生态 & 火山地貌景观和 & 国家级 & 1960 \\
\hline
\end{tabular}




\begin{tabular}{|c|c|c|c|c|c|c|}
\hline $\begin{array}{c}\text { 序号 } \\
\text { Number }\end{array}$ & $\begin{array}{c}\text { 自然保护区名称 } \\
\text { Name of nature } \\
\text { reserve }\end{array}$ & $\begin{array}{c}\text { 面积 } \\
\text { Area (ha) }\end{array}$ & $\begin{array}{l}\text { 类型 } \\
\text { Types }\end{array}$ & $\begin{array}{c}\text { 主要保护对象 } \\
\text { The main protected } \\
\text { objects }\end{array}$ & $\begin{array}{c}\text { 级别 } \\
\text { Levels }\end{array}$ & $\begin{array}{c}\text { 始建时间 } \\
\text { Building } \\
\text { time }\end{array}$ \\
\hline & & & & 森林生态系统 & & \\
\hline 25 & 吉林松花江三湖 & $115,253.2$ & 森林生态 & $\begin{array}{l}\text { 森林及水域生态 } \\
\text { 系统 }\end{array}$ & 国家级 & 1982 \\
\hline 26 & $\begin{array}{l}\text { 黑龙江穆棱东北红 } \\
\text { 豆杉 }\end{array}$ & 35,648 & 野生植物 & $\begin{array}{l}\text { 东北红豆杉及其 } \\
\text { 森林生态系统 }\end{array}$ & 国家级 & 2004 \\
\hline 27 & 吉林珲春东北虎 & 108,700 & 野生动物 & $\begin{array}{l}\text { 东北虎、豹及其栖 } \\
\text { 息地 }\end{array}$ & 国家级 & 2001 \\
\hline 28 & 黑龙江凤凰山 & 26,570 & 森林生态 & $\begin{array}{l}\text { 兴凯松林、东北红 } \\
\text { 豆杉、松茸等野生 } \\
\text { 动植物及森林生 } \\
\text { 态系统 }\end{array}$ & 国家级 & 1989 \\
\hline 29 & 吉林汪清 & 67,434 & 森林生态 & $\begin{array}{l}\text { 东北红豆杉及针 } \\
\text { 阔混交林生态系 } \\
\text { 统 }\end{array}$ & 国家级 & 2002 \\
\hline 30 & 黑龙江牡丹峰 & 19,468 & 森林生态 & 原始森林 & 国家级 & 1981 \\
\hline 31 & $\begin{array}{l}\text { 黑龙江老爷岭东北 } \\
\text { 虎 }\end{array}$ & 71,278 & 野生动物 & $\begin{array}{l}\text { 东北虎、东北豹、 } \\
\text { 猎物种群及温带 } \\
\text { 山地森林生态系 } \\
\text { 统 }\end{array}$ & 国家级 & 2011 \\
\hline 32 & 辽宁老秃顶子 & 15,219 & 森林生态 & $\begin{array}{l}\text { 长白植物区系森 } \\
\text { 林及人参等珍稀 } \\
\text { 物种 }\end{array}$ & 国家级 & 1981 \\
\hline 33 & 吉林哈泥 & 22,230 & 森林生态 & $\begin{array}{l}\text { 以哈泥沼泽为主 } \\
\text { 的湿地生态系统 } \\
\text { 和哈泥河上游水 } \\
\text { 源涵养区 }\end{array}$ & 国家级 & 1991 \\
\hline 34 & 吉林通化石湖 & 15,200 & 森林生态 & $\begin{array}{l}\text { 温带山地森林生 } \\
\text { 态系统及东北红 } \\
\text { 豆杉、朝鲜崖柏 }\end{array}$ & 省级 & 1993 \\
\hline 35 & 辽宁白石砬子 & 7,467 & 森林生态 & $\begin{array}{l}\text { 原生型红松针阔 } \\
\text { 混交林 }\end{array}$ & 国家级 & 1981 \\
\hline 36 & 辽宁仙人洞 & $3,574.7$ & 森林生态 & 森林生态系统 & 国家级 & 1981 \\
\hline 37 & 内蒙古阿鲁科尔沈 & $136,793.6$ & 草原草甸 & $\begin{array}{l}\text { 沙地草原、湿地生 } \\
\text { 态系统及珍稀鸟 } \\
\text { 类 }\end{array}$ & 国家级 & 1999 \\
\hline 38 & 黑龙江绰纳河 & 105,580 & 内陆湿地 & $\begin{array}{l}\text { 寒温带针叶林与 } \\
\text { 温带针阔叶混交 } \\
\text { 林 }\end{array}$ & 国家级 & 2002 \\
\hline
\end{tabular}


郭子良, 邢韶华, 崔国发. 自然保护区物种多样性保护价值评价方法. 生物多样性, 2017, 25 (3): 312-324. http://www.biodiversity-science.net/CN/10.17520/biods.2016350

\begin{tabular}{|c|c|c|c|c|c|c|}
\hline $\begin{array}{c}\text { 序号 } \\
\text { Number }\end{array}$ & $\begin{array}{c}\text { 自然保护区名称 } \\
\begin{array}{c}\text { Name of nature } \\
\text { reserve }\end{array}\end{array}$ & $\begin{array}{c}\text { 面积 } \\
\text { Area (ha) }\end{array}$ & $\begin{array}{l}\text { 类型 } \\
\text { Types }\end{array}$ & $\begin{array}{c}\text { 主要保护对象 } \\
\text { The main protected } \\
\text { objects }\end{array}$ & $\begin{array}{c}\text { 级别 } \\
\text { Levels }\end{array}$ & $\begin{array}{c}\text { 始建时间 } \\
\text { Building } \\
\text { time }\end{array}$ \\
\hline 39 & 黑龙江多布库尔 & 128,959 & 内陆湿地 & $\begin{array}{l}\text { 寒温带湿地生态 } \\
\text { 系统及野生动植 } \\
\text { 物 }\end{array}$ & 国家级 & 2002 \\
\hline 40 & 黑龙江双河 & 88,849 & 内陆湿地 & $\begin{array}{l}\text { 寒温带森林生态 } \\
\text { 系统、森林沼泽系 } \\
\text { 统及濒危物种 }\end{array}$ & 国家级 & 2002 \\
\hline 41 & 黑龙江库尔滨河 & 66,964 & 内陆湿地 & $\begin{array}{l}\text { 湿地水域生态系 } \\
\text { 统及冷水鱼类 }\end{array}$ & 省级 & 2004 \\
\hline 42 & 黑龙江大沾河湿地 & 211,618 & 内陆湿地 & $\begin{array}{l}\text { 小兴安岭林区森 } \\
\text { 林湿地生态系统, } \\
\text { 白头鹤等水禽及 } \\
\text { 其栖息地及温带 } \\
\text { 森林生态系统 }\end{array}$ & 国家级 & 2001 \\
\hline 43 & 黑龙江公别拉河 & 47,983 & 内陆湿地 & $\begin{array}{l}\text { 沼泽湿地生态系 } \\
\text { 统及珍稀野生动 } \\
\text { 植物 }\end{array}$ & 省级 & 2005 \\
\hline 44 & 黑龙江红星湿地 & 111,995 & 内陆湿地 & $\begin{array}{l}\text { 温带森林湿地生 } \\
\text { 态系统 }\end{array}$ & 国家级 & 2001 \\
\hline 45 & 黑龙江翠北湿地 & 27,730 & 内陆湿地 & $\begin{array}{l}\text { 森林湿地生态系 } \\
\text { 统及其湿地动植 } \\
\text { 物 }\end{array}$ & 省级 & 2001 \\
\hline 46 & 黑龙江山口 & $99,489.9$ & 内陆湿地 & $\begin{array}{l}\text { 内陆湿地生态系 } \\
\text { 统 }\end{array}$ & 省级 & 2002 \\
\hline 47 & 黑龙江乌伊岭 & 43,824 & 内陆湿地 & $\begin{array}{l}\text { 温带森林森林生 } \\
\text { 态系统、沼泽湿地 } \\
\text { 生态系统 }\end{array}$ & 国家级 & 1999 \\
\hline 48 & 黑龙江细鳞河 & 20,617 & 内陆湿地 & $\begin{array}{l}\text { 森林、湿地生态系 } \\
\text { 统及琋动物 }\end{array}$ & 省级 & 2004 \\
\hline 49 & 黑龙江新青白头鹤 & 62,567 & 野生动物 & $\begin{array}{l}\text { 白头鹤、驼鹿等珍 } \\
\text { 稀动物及北温带 } \\
\text { 森林生态系统和 } \\
\text { 湿地生态系统 }\end{array}$ & 国家级 & 2004 \\
\hline 50 & 吉林波罗湖 & 24,915 & 内陆湿地 & $\begin{array}{l}\text { 湿地生态系统及 } \\
\text { 鹤、鹤类珍稀濒危 } \\
\text { 鸟类 }\end{array}$ & 国家级 & 2004 \\
\hline 51 & 吉林莫莫格 & 144,000 & 内陆湿地 & $\begin{array}{l}\text { 鹤、鹳类等珍稀水 } \\
\text { 禽及湿地生态系 } \\
\text { 统 }\end{array}$ & 国家级 & 1981 \\
\hline 52 & 黑龙江扎龙 & 210,000 & 野生动物 & 丹顶鹤等珍禽及 & 国家级 & 1987 \\
\hline
\end{tabular}


郭子良, 邢韶华, 崔国发. 自然保护区物种多样性保护价值评价方法. 生物多样性, 2017, 25 (3): 312-324. http://www.biodiversity-science.net/CN/10.17520/biods.2016350

\begin{tabular}{|c|c|c|c|c|c|c|}
\hline $\begin{array}{l}\text { 序号 } \\
\text { Number }\end{array}$ & $\begin{array}{c}\text { 自然保护区名称 } \\
\text { Name of nature } \\
\text { reserve }\end{array}$ & $\begin{array}{c}\text { 面积 } \\
\text { Area (ha) }\end{array}$ & $\begin{array}{l}\text { 类型 } \\
\text { Types }\end{array}$ & $\begin{array}{c}\text { 主要保护对象 } \\
\text { The main protected } \\
\text { objects }\end{array}$ & $\begin{array}{c}\text { 级别 } \\
\text { Levels }\end{array}$ & $\begin{array}{c}\text { 始建时间 } \\
\text { Building } \\
\text { time }\end{array}$ \\
\hline & & & & 湿地生态系统 & & \\
\hline 53 & 黑龙江乌裕尔河 & 55,423 & 内陆湿地 & $\begin{array}{l}\text { 湿地生态系统及 } \\
\text { 丹顶鹤、老铇等珍 } \\
\text { 稀水禽 }\end{array}$ & 国家级 & 1992 \\
\hline 54 & 吉林查干湖 & 50,684 & 内陆湿地 & $\begin{array}{l}\text { 湿地生态系统及 } \\
\text { 珍稀鸟类 }\end{array}$ & 国家级 & 1986 \\
\hline 55 & 黑龙江明水 & 30,840 & 内陆湿地 & $\begin{array}{l}\text { 平原沼泽湿地生 } \\
\text { 态系统及大铇等 } \\
\text { 珍稀野生动植物 }\end{array}$ & 国家级 & 2007 \\
\hline 56 & 辽宁辽河口 & 80,000 & 野生动物 & $\begin{array}{l}\text { 珍稀水禽及沿海 } \\
\text { 湿地生态系统 } \\
\text { 湿地生态系统及 }\end{array}$ & 国家级 & 1985 \\
\hline 57 & 黑龙江兴凯湖 & 222,488 & 内陆湿地 & $\begin{array}{l}\text { 丹顶鹤等珍稀鸟 } \\
\text { 类 }\end{array}$ & 国家级 & 1986 \\
\hline 58 & 黑龙江黑瞎子岛 & 12,417 & 内陆湿地 & $\begin{array}{l}\text { 湿地生态系统及 } \\
\text { 濒危水鸟 }\end{array}$ & 省级 & 2014 \\
\hline 59 & 黑龙江东方红湿地 & 31,516 & 内陆湿地 & $\begin{array}{l}\text { 湿地生态系统和 } \\
\text { 濒危动植物 }\end{array}$ & 国家级 & 2001 \\
\hline 60 & 黑龙江三环泡 & 27,687 & 内陆湿地 & $\begin{array}{l}\text { 湿地生态系统及 } \\
\text { 丹顶鹤、天鹅、小 } \\
\text { 叶樟 }\end{array}$ & 国家级 & 1991 \\
\hline 61 & 黑龙江三江 & 198,089 & 内陆湿地 & $\begin{array}{l}\text { 湿地生态系统及 } \\
\text { 东方白鹳等珍禽 }\end{array}$ & 国家级 & 1994 \\
\hline 62 & 黑龙江珍宝岛 & 44,364 & 内陆湿地 & $\begin{array}{l}\text { 湿地生态系统和 } \\
\text { 珍稀濒危动植物 }\end{array}$ & 国家级 & 2002 \\
\hline 63 & 黑龙江大佳河 & 71,932 & 内陆湿地 & $\begin{array}{l}\text { 湿地、森林生态系 } \\
\text { 统及珍稀野生动 } \\
\text { 植物 }\end{array}$ & 省级 & 2004 \\
\hline 64 & 吉林雁鸣湖 & 53,940 & 内陆湿地 & 湿地生态系统 & 国家级 & 1991 \\
\hline 65 & 黑龙江镜泊湖 & 126,000 & 内陆湿地 & $\begin{array}{l}\text { 水域、森林生态系 } \\
\text { 统及火山口、熔 } \\
\text { 洞、熔岩台地等地 } \\
\text { 质地貌 }\end{array}$ & 省级 & 1980 \\
\hline 66 & 吉林龙湾 & 15,061 & 内陆湿地 & $\begin{array}{l}\text { 湿地、森林生态系 } \\
\text { 统及火山湖泊 }\end{array}$ & 国家级 & 1991 \\
\hline 67 & 辽宁蛇岛老铁山 & 9,072 & 野生动物 & $\begin{array}{l}\text { 蝮蛇、候鸟及蛇岛 } \\
\text { 特殊生态系统 }\end{array}$ & 国家级 & 1980 \\
\hline
\end{tabular}

